\title{
Polymorphism and Structural Distortions of Mixed-Metal Oxide Photocatalysts Constructed with $\alpha-\mathrm{U}_{3} \mathrm{O}_{8}$ Types of Layers
}

\author{
Nacole King ${ }^{1, *}$, Jonathan Boltersdorf ${ }^{2}$, Paul A. Maggard ${ }^{3}$ and Winnie Wong-Ng ${ }^{1}$ \\ 1 National Institute for Standards and Technology, Materials Measurement Science Division, \\ 100 Bureau Drive, Gaithersburg, MD 20899, USA; winnie.wong-ng@nist.gov \\ 2 United States Army Research Laboratory, Sensors and Electron Devices Directorate, \\ Adelphi, MD 20783, USA; jonathan.a.boltersdorf.ctr@mail.mil \\ 3 North Carolina State University, Department of Chemistry, Raleigh, NC 27695, USA; pamaggar@ncsu.edu \\ * Correspondence: nacole.king@nist.gov; Tel.: +301-975-5166
}

Academic Editor: Helmut Cölfen

Received: 12 April 2017; Accepted: 14 May 2017; Published: 18 May 2017

\begin{abstract}
A series of mixed-metal oxide structures based on the stacking of $\alpha-\mathrm{U}_{3} \mathrm{O}_{8}$ type pentagonal bipyramid layers have been investigated for symmetry lowering distortions and photocatalytic activity. The family of structures contains the general composition $\mathrm{A}^{m+}{ }_{((n+1) / m)} \mathrm{B}_{(3 n+1)} \mathrm{O}_{(8 n+3)}$ (e.g., $\mathrm{A}=\mathrm{Ag}, \mathrm{Bi}, \mathrm{Ca}, \mathrm{Cu}, \mathrm{Ce}, \mathrm{Dy}, \mathrm{Eu}, \mathrm{Gd} \mathrm{K}, \mathrm{La}, \mathrm{Nd}, \mathrm{Pb}, \mathrm{Pr}, \mathrm{Sr}, \mathrm{Y} ; \mathrm{B}=\mathrm{Nb}, \mathrm{Ta} ; m=1-3 ; n=1,1.5,2)$, and the edge-shared $\mathrm{BO}_{7}$ pentagonal pyramid single, double, and/or triple layers are differentiated by the average thickness, (i.e., $1 \leq n \leq 2$ ), of the $\mathrm{BO}_{7}$ layers and the local coordination environment of the " $\mathrm{A}$ " site cations. Temperature dependent polymorphism has been investigated for structures containing single layered $(n=1)$ monovalent $(m=1)$ " $\mathrm{A}$ " site cations (e.g., $\mathrm{Ag}_{2} \mathrm{Nb}_{4} \mathrm{O}_{11}, \mathrm{Na}_{2} \mathrm{Nb}_{4} \mathrm{O}_{11}$, and $\mathrm{Cu}_{2} \mathrm{Ta}_{4} \mathrm{O}_{11}$ ). Furthermore, symmetry lowering distortions were observed for the $\mathrm{Pb}$ ion-exchange synthesis of $\mathrm{Ag}_{2} \mathrm{Ta}_{4} \mathrm{O}_{11}$ to yield $\mathrm{PbTa}_{4} \mathrm{O}_{11}$. Several members within the subset of the family have been constructed with optical and electronic properties that are suitable for the conversion of solar energy to chemical fuels via water splitting.
\end{abstract}

Keywords: photocatalysis; mixed-metal oxide; structural distortion

\section{Introduction}

Many properties and applications of inorganic materials are derived from a small number of reported structure types. Structural families of metal-oxides that have been commonly explored in the literature are $\mathrm{ABO}_{3}$ pervoskites [1-5], layered Ruddelsden-Popper pervoskites [6-8], and spinel structures [9-11]. Metal-oxide materials can also be classified by their properties that can include superconductors [12-15], transparent conducting oxides [16-20], and photocatalysts [21-26]. Variations of compositions within homologous families of structures exhibit important structural transformations (i.e., structural distortions, polymorphism) which impact their optical properties (i.e., range of light absorption for photocatalysis). A family of structures based on the stacking of $\alpha-\mathrm{U}_{3} \mathrm{O}_{8}$ type layers constructed with pentagonal bipyramids is the focus of this review, wherein condensed $\mathrm{MO}_{7}(\mathrm{M}=\mathrm{Nb}$, Ta) polyhedra have been found to underlie interesting new polymorphism, structural distortions, and activity for photocatalytic water splitting.

The crystal structure of $\mathrm{U}_{3} \mathrm{O}_{8}$ was first proposed by Zachariasen [27], further investigations of the single crystal and neutron diffraction confirmed the orthorhombic crystal structure of $\mathrm{U}_{3} \mathrm{O}_{8}$ [28-30]. At room temperature two crystalline forms of $\mathrm{U}_{3} \mathrm{O}_{8}$ can be synthesized. The $\alpha-\mathrm{U}_{3} \mathrm{O}_{8}$ phase is the form obtained under typical synthetic conditions; however, under special circumstances the $\beta-\mathrm{U}_{3} \mathrm{O}_{8}$ form 
can be crystalized [31]. The $\alpha-\mathrm{U}_{3} \mathrm{O}_{8}$ structure undergoes a phase transition from an orthorhombic unit cell to a hexagonal unit cell at $\approx 210{ }^{\circ} \mathrm{C}$ [32-34]. A polysomatic family of structures with the general composition $\mathrm{A}^{m+}{ }_{((n+1) / m)} \mathrm{B}_{(3 n+1)} \mathrm{O}_{(8 n+3)}$ (e.g., $\mathrm{A}=\mathrm{Ag}, \mathrm{Bi}, \mathrm{Ca}, \mathrm{Cu}, \mathrm{Ce}, \mathrm{Dy}, \mathrm{Eu}, \mathrm{Gd}, \mathrm{K}, \mathrm{La}, \mathrm{Nd}, \mathrm{Pb}, \mathrm{Pr}, \mathrm{Sr}, \mathrm{Y}$; $\mathrm{B}=\mathrm{Nb}, \mathrm{Ta} ; n=1,1.5,2 ; m=1-3)$ have been constructed with $\alpha-\mathrm{U}_{3} \mathrm{O}_{8}$ type layers comprised of mixed six-, seven-, and eight-coordination sites [35]. Synthesis and structural investigations of these systems were first described in detail by Jahnberg [36-38]. Furthermore, several of the structures in the system display symmetry lowering distortions, and unique optical and electronic properties that are viable for the direct conversion of solar energy into chemical fuels.

\section{2. $\alpha-\mathrm{U}_{3} \mathrm{O}_{8}$ Type Structural Layers}

The orthorhombic crystal structure of $\alpha-\mathrm{U}_{3} \mathrm{O}_{8}$ (space group Amm2 (\#38) $a=4.14(8) \AA$, $b=11.96(6) \AA, c=6.71(7) \AA)$ consists of layers of edge-shared pentagonal bipyramids along the (110) direction [30]. In each layer a maximum of four edges can be shared, leaving one unshared edge per polyhedron [36]. An isolated $\mathrm{UO}_{7}$ pentagonal bipyramid layer is built from $\mathrm{U}_{3} \mathrm{O}_{5+6 / 2}$ layers, where $6 / 2$ are the six shared apical oxygen atoms between alternating layers, thereby yielding the $\mathrm{U}_{3} \mathrm{O}_{8}$ chemical composition [37]. The average interatomic distances between six nearby $\mathrm{O}$ atoms for $\mathrm{U} 1$ and $\mathrm{U} 2$ are between $2.07 \AA-2.23 \AA$, with each $\mathrm{U}$ atom having a longer interatomic distance for a seventh $\mathrm{O}$ atom $2.44 \AA$ (U1) and $2.71 \AA$ (U2). An edge shared layer of $\mathrm{UO}_{7}$ polyhedra and an isolated $\mathrm{UO}_{7}$ pentagonal bipyramid labeled with average atomic distances and a single edge-shared polyhedra are shown in Figure 1a,b, respectively. This edge-shared pentagonal bipyramid layer is the principle building block for a polysomatic family of structures with the general composition $\mathrm{A}^{m+}{ }_{((n+1) / m)} \mathrm{B}_{(3 n+1)} \mathrm{O}_{(8 n+3)}$ (e.g., $\mathrm{A}=\mathrm{Ag}, \mathrm{Bi}, \mathrm{Ca}, \mathrm{Cu}, \mathrm{Ce}, \mathrm{Dy}, \mathrm{Eu}, \mathrm{Gd}, \mathrm{K}, \mathrm{La}, \mathrm{Nd}, \mathrm{Pb}, \mathrm{Pr}, \mathrm{Sr}, \mathrm{Y} ; \mathrm{B}=\mathrm{Nb}, \mathrm{Ta} ; n=1,1.5,2 ; m=1-3)$. These ternary mixed-metal oxides are constructed from pentagonal bipyramidal layers, similar to the layers observed in $\alpha-\mathrm{U}_{3} \mathrm{O}_{8}$, where $n$ defines the average thickness $(1 \leq n \leq 2)$ of the $\mathrm{BO}_{7}$ layers [35]. Furthermore, these structures are comprised of either 2, 7, or 8 coordination sites for the A-site cation, and layers of single, double, and triple layers of edge-shared pentagonal bipyramids. The crystal structures are comprised of edge-shared pentagonal bipyramid polyhedra that stack in single, double, and triple layers, as shown in Figure 2.

a

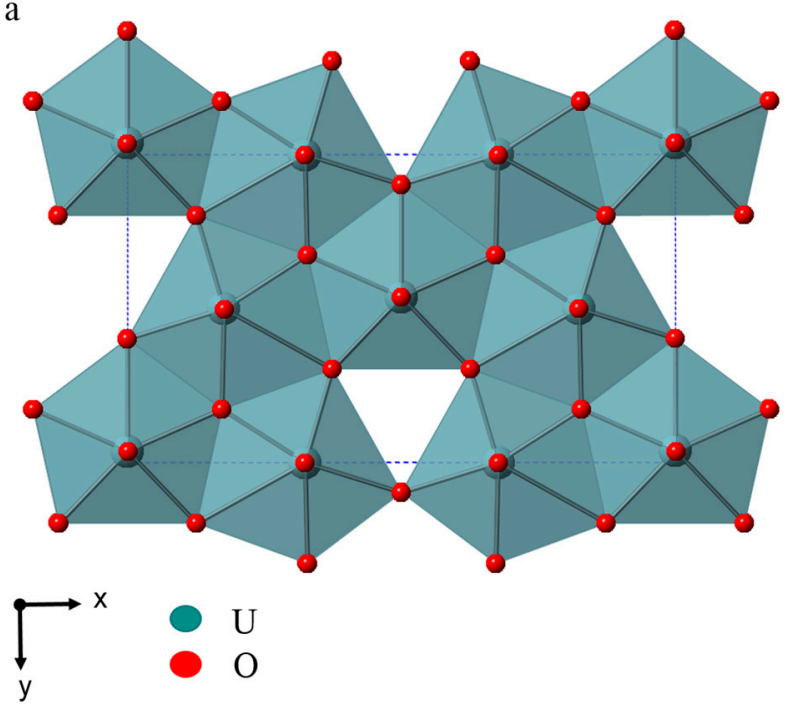

$\mathrm{b}$

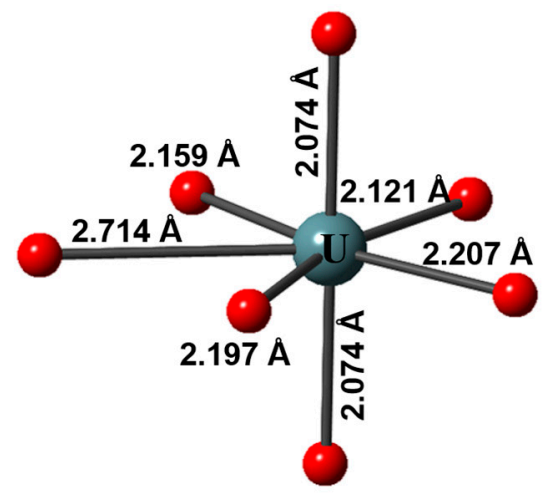

Figure 1. (a) Polyhedral view of the crystal structure of $\alpha-\mathrm{U}_{3} \mathrm{O}_{8}$ showing the edge-shared $\mathrm{UO}_{7}$ pentagonal bipyramid layer in the (001) plane and (b) the local pentagonal bipyramidal coordination environment of a $U$ cation annotated with interatomic distances. 
a
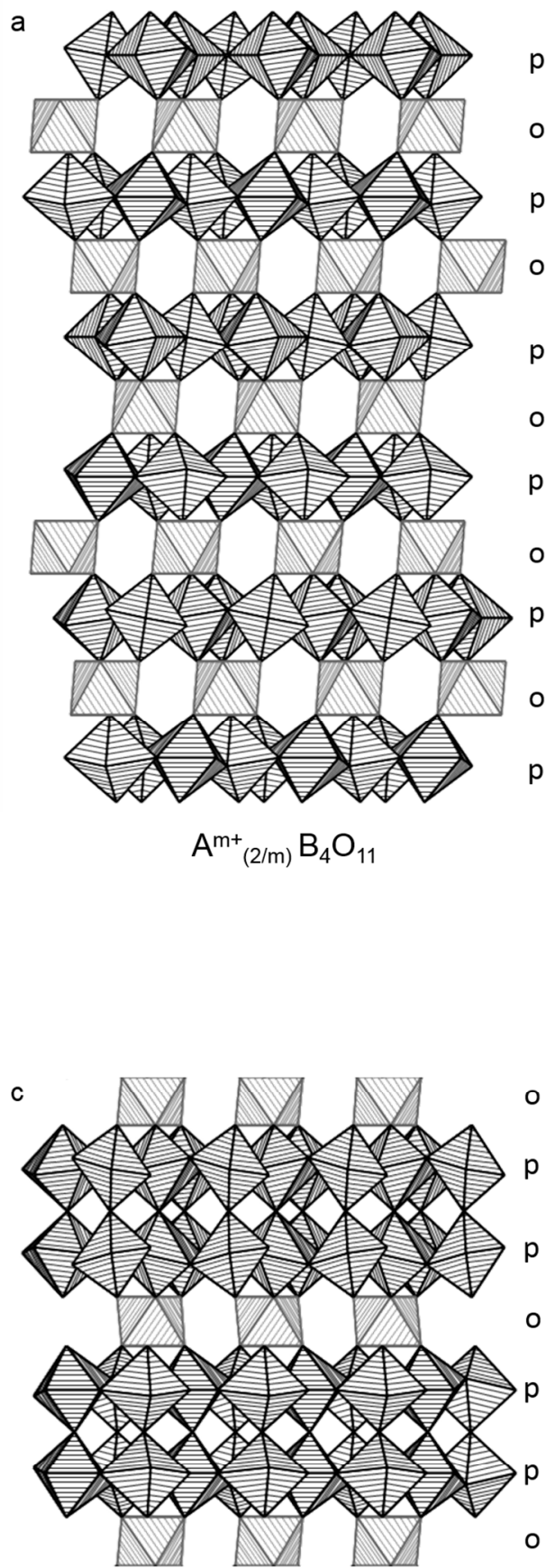

$\mathrm{A}_{\mathrm{x}} \mathrm{Ta}_{7} \mathrm{O}_{19}$

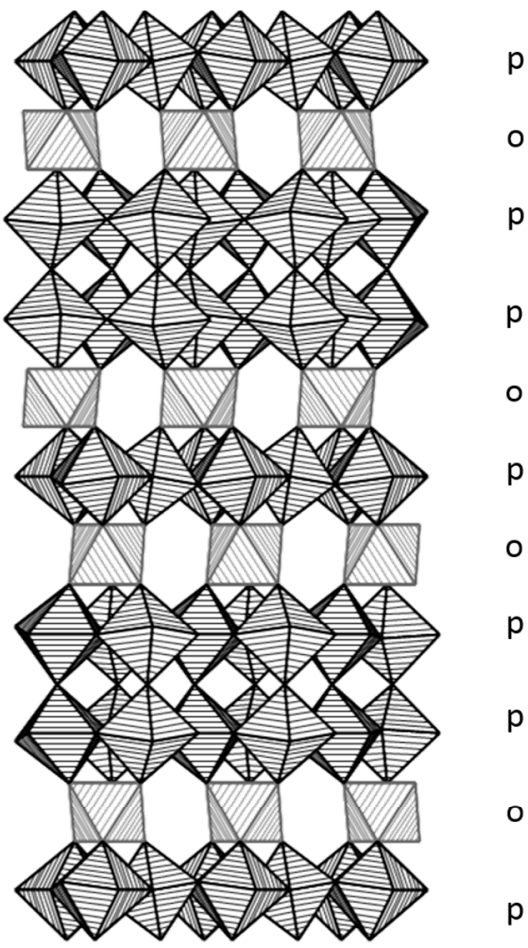

$\mathrm{A}_{\mathrm{x}} \mathrm{B}_{11} \mathrm{O}_{30}$

d

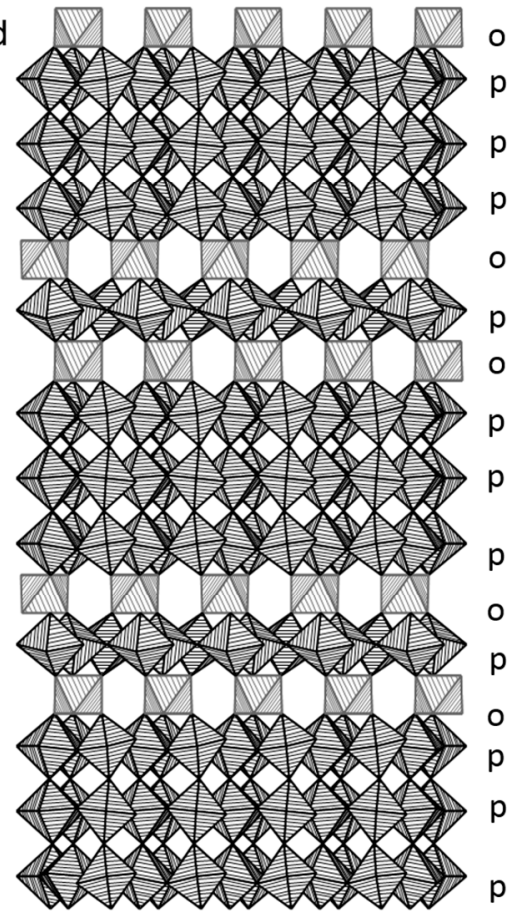

$\mathrm{A}_{\mathrm{x}} \mathrm{Nb}_{7} \mathrm{O}_{19}$

Figure 2. The crystal structures constructed from $\alpha-\mathrm{U}_{3} \mathrm{O}_{8}$ type layers with the general composition $\mathrm{A}^{\mathrm{m}+}{ }_{((\mathrm{n}+1) / \mathrm{m})} \mathrm{B}_{(3 \mathrm{n}+1)} \mathrm{O}_{(8 \mathrm{n}+3)}$ (a) single; (b) alternating single and double; (c) double; and (d) alternating single and triple layers of edge-shared pentagonal bipyramid polyhedra. These layers alternate with layers of isolated octahedra along the (001) direction. The grey (o) and black (p) striped polyhedra represent $\mathrm{BO}_{6}$ octahedral and $\mathrm{BO}_{7}$ layers, respectively. 


\subsection{Single Layers}

Crystal structures comprised of single pentagonal bipyramidal layers have been observed for the subset of metal oxides with the general composition $\mathrm{A}^{m+}{ }_{(2 / m)} \mathrm{B}_{4} \mathrm{O}_{11}(\mathrm{~A}=\mathrm{Ag}, \mathrm{Ca}, \mathrm{Cu}, \mathrm{K}, \mathrm{Na}$, $\mathrm{Pb}, \mathrm{Sr} ; \mathrm{B}=\mathrm{Nb}, \mathrm{Ta} ; m=1,2)$ [37-39]. These layers of $\mathrm{MO}_{7}$ polyhedra alternate with layers of $\mathrm{MO}_{6}$ octahedra in a $\mathrm{p}-\mathrm{O}-\mathrm{p}-\mathrm{o}(\mathrm{o}=$ octahedra, $\mathrm{p}=$ pentagonal bipyramid $)$ pattern, as shown in Figure $2 \mathrm{a}$. Individual structural views of each type of layer are shown in Figure 3a-d. The apical $\mathrm{O}$ atoms of the single layers of edge-shared $\mathrm{Nb}$ /Ta pentagonal bipyramids form the intervening coordination environments (from above and below) for the layers of $\mathrm{Nb} / \mathrm{Ta}$ octahedra and A-site cations. Each $\mathrm{BO}_{6}$ octahedral environment can accommodate either three $(m=2)$ or six $(m=1)$ A-site cations that are 2, 6,7 , or 8-coordinate depending on their oxidation state, size, and coordination preference. Linearly coordinated cations have solely been observed for $\mathrm{Cu}$-containing compounds (e.g., $\mathrm{Cu}_{2} \mathrm{Ta}_{4} \mathrm{O}_{11}$ ) where $\mathrm{Cu}$ vacancies are found to occur over 33\% of the available $\mathrm{Cu}$ sites [40]. There are six nearest neighbor $\mathrm{O}$ atoms for coordination to the A-site cations in the $\mathrm{Ag} / \mathrm{K}$ tantalates and the $\mathrm{Ag} / \mathrm{Na}$ niobates. The coordination number for the $\mathrm{Na} / \mathrm{Pb}$ cations in $\mathrm{Na}_{2} \mathrm{Ta}_{4} \mathrm{O}_{11}$ and $\mathrm{PbTa}_{4} \mathrm{O}_{11}$ is 7 , owing to an increase of a single nearest neighbor $\mathrm{O}$ atom in comparison to $\mathrm{Na}_{2} \mathrm{Nb}_{4} \mathrm{O}_{11}$. The crystal structure for $\mathrm{CaTa}_{4} \mathrm{O}_{11}$ is shown in Figure 3d, where the $\mathrm{Ca}^{2+}$ and $\mathrm{Sr}^{2+}$ cations are surrounded by eight nearest neighbor $\mathrm{O}$ atoms. Alternating octahedral and pentagonal bipyramidal layers are mirror images of one another; thus, upper and lower faces of the $\mathrm{BO}_{6}(\mathrm{~B}=\mathrm{Nb}, \mathrm{Ta})$ octahedron cavity are formed from three oxygen atoms in the layer above and from three oxygen atoms in the layer below [36]. The layers are bridged through the apical vertices of $\mathrm{BO}_{7}\left(\mathrm{~B}=\mathrm{Nb}\right.$, Ta) pentagonal bipyramids that are perpendicular to $\mathrm{BO}_{6}$ $(\mathrm{B}=\mathrm{Nb}, \mathrm{Ta})$ octahedral layers. The interatomic distances for 7 -coordinate $\mathrm{Nb} / \mathrm{Ta}$ polyhedra are included in Table S1.

a

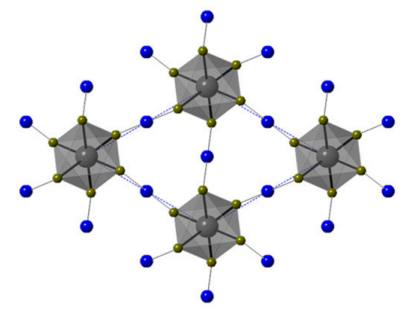

c

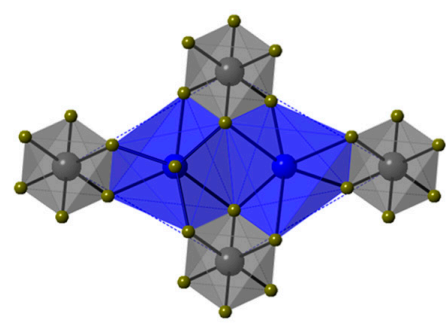

b
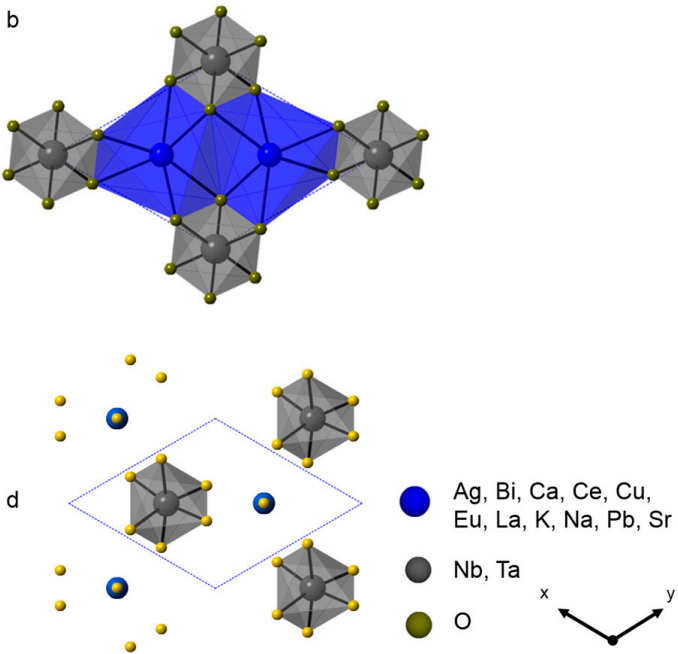

Figure 3. Polyhedral view of the $\mathrm{MO}_{6}$ layer $(\mathrm{M}=\mathrm{Nb}$ or Ta), illustrating the occurrence of (a) 2- (b) 6(c) 7- (d) 8-fold coordination number for the A site cations that stack in single, double, and triple $(\mathrm{Nb} / \mathrm{Ta}) \mathrm{O}_{7}$ layers.

The rhombohedral $R \overline{3} c$ space group is observed for members of the $\mathrm{A}^{m+}{ }_{(2 / m)} \mathrm{B}_{4} \mathrm{O}_{11}$ subset of structures where the A-site cation is monovalent $(m=1)$. Although the symmetry of the compositions $\mathrm{Ag}_{2} \mathrm{Nb}_{4} \mathrm{O}_{11}, \mathrm{Ag}_{2} \mathrm{Ta}_{4} \mathrm{O}_{11}, \mathrm{Cu}_{2} \mathrm{Ta}_{4} \mathrm{O}_{11}, \mathrm{Na}_{2} \mathrm{Nb}_{4} \mathrm{O}_{11}, \mathrm{Na}_{2} \mathrm{Ta}_{4} \mathrm{O}_{11}$, and $\mathrm{K}_{2} \mathrm{Ta}_{4} \mathrm{O}_{11}$ are similar, the coordination geometries of the A-site cations vary as previously mentioned. Babaryk et al., reported increasing the calculated polyhedral volume of $\mathrm{MO}_{\mathrm{x}}(x=6-8)$ leads to successful transformations from centrosymmetric to noncentrosymmetric space groups [41]. However, $\mathrm{Na}_{2} \mathrm{Nb}_{4} \mathrm{O}_{11}$ and $\mathrm{Ag}_{2} \mathrm{Nb}_{4} \mathrm{O}_{11}$ are not polar at room temperature, and are classified in a rhomobohedral R3c and monoclinic $\mathrm{C} 2 / \mathrm{c}$ space groups, respectively [42,43]. Table S2 in the Supporting Information indicates three general trends for extended structures with the composition $\mathrm{A}^{m+}{ }_{(2 / m)} \mathrm{B}_{4} \mathrm{O}_{11}$ : (1) an increase in the " $\mathrm{A}$ " site 
coordination number is directly correlated to decreasing $c$ lattice constant parameters; (2) members where $m=1$ belong to centrosymmetric nonpolar space groups which contain an inversion center; and (3) members where $m=2$ belong to noncentrosymmetric polar space that do not contain an inversion center. Symmetry-lowering structural distortions have been reported for the monovalent A-site niobate cations $\mathrm{Na}$ and $\mathrm{Ag}$, as well as the monovalent " $\mathrm{A}$ "site $\mathrm{Cu}$ cation in the tantalate structures, which will be further discussed in a separate section of this review.

\subsection{Alternating Single and Double Layers}

The $\mathrm{Cu}_{5} \mathrm{Ta}_{11} \mathrm{O}_{30}$ and $\operatorname{Pr}_{2} \mathrm{Nb}_{11} \mathrm{O}_{30}$ compounds are members of the subgroup of structures that are comprised of alternating layers of single and double $(\mathrm{Nb} / \mathrm{Ta}) \mathrm{O}_{7}$ pentagonal bipyramids [44-46] shown in Figure $2 b$. The members of this subset of structures are arranged in a stacking scheme constructed with octahedral (o) and pentagonal bipyramid (p) layers in a p-o-p-p-o order. The edge-shared pentagonal bipyramid layers and layers of isolated $\mathrm{BO}_{6}$ octahedra surrounded by 2- or 8-coordinated $\mathrm{Cu}$ (I) or Pr cations in Figure 3a,d, respectively. As previously observed for Cu-containing structures comprised of layers of edge-shared pentagonal bipyramids, the $\mathrm{Cu}$ atoms in $\mathrm{Cu}_{5} \mathrm{Ta}_{11} \mathrm{O}_{30}$ are also linearly coordinated and contain $\mathrm{Cu}$ vacancies, where $5 / 6$ of the $\mathrm{Cu}$ sites are occupied[44,47]. Furthermore, the $\mathrm{Cu}$-containing phase with the theoretical composition $\mathrm{Cu}_{7} \mathrm{Ta}_{15} \mathrm{O}_{41}$ was observed as a side product during the $\mathrm{Cu}_{5} \mathrm{Ta}_{11} \mathrm{O}_{30}$ phase analysis study by Jahnberg [48] and indexed on a hexagonal unit cell in the $\mathrm{P}_{3} / \mathrm{m}$ space group. The $\mathrm{Pr}_{2} \mathrm{Nb}_{11} \mathrm{O}_{30}$ compound is structurally related to $\mathrm{Cu}_{5} \mathrm{Ta}_{11} \mathrm{O}_{30}$ and is the only known example that appears to be partially reduced (i.e., $\approx 9.1 \% \mathrm{Nb}^{4+}$ to $\approx 90.9 \% \mathrm{Nb}^{5+}$ ) within the Jahnberg structural family [49]. The structure is comprised of one symmetry unique $\operatorname{Pr}$ (III) cation coordinated to eight near-neighbor $\mathrm{O}$ atoms and three symmetry unique $\mathrm{Nb}$ cations, where $\mathrm{Nb} 1$ and $\mathrm{Nb} 2$ are edge shared $\mathrm{NbO}_{7}$ polyhedra, and $\mathrm{Nb} 3$ is octahedrally coordinated to surrounding $\mathrm{O}$ atoms. Selected crystallographic information for $\mathrm{Cu}_{5} \mathrm{Ta}_{11} \mathrm{O}_{30}, \mathrm{Cu}_{7} \mathrm{Ta}_{15} \mathrm{O}_{41}$, and $\mathrm{Pr}_{2} \mathrm{Nb}_{11} \mathrm{O}_{30}$ are included in Table S3 in the Supporting Information.

\subsection{Double Layers}

The subset of structures composed exclusively with double layers of edge-shared $\mathrm{TaO}_{7}(\mathrm{~B}=\mathrm{Ta})$ pentagonal bipyramids occur with the general formula $\mathrm{A}^{m+}{ }_{((n+1) / m)} \mathrm{Ta}_{7} \mathrm{O}_{19}(\mathrm{~A}=\mathrm{Bi}, \mathrm{Cu}, \mathrm{Ce}, \mathrm{Dy}, \mathrm{Eu}$, $\mathrm{Gd}, \mathrm{La}, \mathrm{Nd}, \mathrm{Sm}, \mathrm{Y} ; m=1,3 ; n=1.5,2)[35,40,46,50-53]$. Members of this subset are constructed with octahedra (o) and pentagonal bipyramids (p) in the following stacking pattern p-p-o-p-p-o as shown in Figure 2c. Similar to the A-site cations in the sub-group of structures composed of single layers and alternating layers of single double pentagonal bipyramids, $\mathrm{Cu}$-containing cations $(m=1)$ within the branch of structures composed of double layers of $\mathrm{TaO}_{7}$ pentagonal bipyramids are linearly coordinated to $\mathrm{O}$ atoms as shown in Figure 3a. With the exception of $\mathrm{Cu}$, the A-site cations, i.e., Bi, $\mathrm{Ce}$, $\mathrm{Eu}, \mathrm{Dy}, \mathrm{La}, \mathrm{Y}(m=3)$, are coordinated to eight nearby $\mathrm{O}$ atoms within the layer containing isolated $\mathrm{TaO}_{6}$ octahedra. Linearly coordinated $\mathrm{Cu}$ and 8-coordinated A-site cations are shown in Figure 3a. Similar to the single layered structures, the double-layered structure is constructed of mirrored images of alternating octahedral and pentagonal bipyramidal layers bridged through the apical vertices of the $\mathrm{TaO}_{7}$. The interatomic distances for $\mathrm{TaO}_{7}$ polyhedra of selected compounds are listed in Table S4.

The members constructed with double layers of $\mathrm{TaO} 7$ pentagonal bipyramids can be classified to the hexagonal crystal systems, (i.e., $\mathrm{P} 6_{3} / \mathrm{m}, \mathrm{P} \overline{6} \mathrm{c} 2$, and $\mathrm{P} 6_{3} / \mathrm{mcm}$ ) as listed in Table S4. Very early investigations by Chretien and Bodit found that the rare earth tantalates, $\mathrm{ATa}_{7} \mathrm{O}_{19}(\mathrm{~A}=\mathrm{Ce}, \mathrm{Eu}, \mathrm{Gd}$, $\mathrm{La}, \mathrm{Nd}, \mathrm{Pr}, \mathrm{Sm}$,) are isostructural to $\mathrm{CeTa}_{7} \mathrm{O}_{19}$ indexed on a tetragonal unit cell, as found using powder X-ray diffraction [54,55]. Further powder X-ray and single crystal investigations by Rossel and Gatehouse concluded $\mathrm{CeTa}_{7} \mathrm{O}_{19}$ crystalizes in the hexagonal system, and includes the other known rare earth tantalates. $[50,53,56]$. Similarily, $\mathrm{YTa}_{7} \mathrm{O}_{19}$ was indexed on a hexagonal unit cell, space group determination among the $\mathrm{P}_{3} / \mathrm{m}, \mathrm{P} \bar{c} \mathrm{c} 2$, and $\mathrm{P}_{3} / \mathrm{mcm}$ was not distinguishable [53]. Niobium containing chemical compositions with the general formula $\mathrm{A}^{m+}{ }_{((n+1) / m)} \mathrm{Nb}_{7} \mathrm{O}_{19}$ cations have also been found, and are composed of triple $\mathrm{NbO}_{7}$ layers, as described below. 


\subsection{Alternating Single and Triple Layers}

Hofmann and Gruehn synthesized and reported a subset of lanthanide rare earth structures with the general composition $\mathrm{A}^{m+}{ }_{((n+1) / m)} \mathrm{Nb}_{7} \mathrm{O}_{19}(\mathrm{~A}=\mathrm{Ce}, \mathrm{La} ; m=3 ; n=2)$ [57]. These rare earth mixed-metal oxide structures are comprised of triple $\mathrm{NbO}_{7}$ pentagonal bipyramid layers alternating with 8-coordinated $\mathrm{La}$ and $\mathrm{Nb}$ octahedra, as shown in Figure 2d. A single crystal investigation of $\mathrm{LaNb}_{7} \mathrm{O}_{19}$ confirmed that it crystallizes in the trigonal space group, $P 3$ [57]. Its structure is composed of eight-coordinated $\mathrm{La}^{3+}$ cations that form distorted square antiprisms and $\mathrm{Nb}$ cations in distorted octahedra which are linked together via corner shared $\mathrm{O}$ atoms as shown in Figure 3. The $\alpha-\mathrm{U}_{3} \mathrm{O}_{8}$-type layers of $\mathrm{NbO}_{7}$ are mirror images of one another and alternate with the following stacking scheme p-o-p-p-p-o ( $p=$ pentagonal bipyramid and o = octahedra), as shown in Figure 4. Each type of niobate layer is constructed from its own symmetry unique $\mathrm{Nb}$ cation, where $\mathrm{Nb} 1-4$ are layers of pentagonal bipyramids and $\mathrm{Nb} 5$ and $\mathrm{Nb} 6$ are the layers of octahedra. The structures $\mathrm{LaNb}_{7} \mathrm{O}_{19}$ and $\mathrm{CeNb}_{7} \mathrm{O}_{19}$ are the first example of a trigonal member within the family of structures. A single crystal investigation was not carried out for $\mathrm{CeNb}_{7} \mathrm{O}_{19}$, the assumption of an isotype with $\mathrm{LaNb}_{7} \mathrm{O}_{19}$ is based on the consistency of the reflections from Guinean diagrams via powder X-ray diffraction [57]. From the investigation, it cannot be ruled out that $\mathrm{Ce}^{4+}$ may occupy the $\mathrm{La}^{3+}$ and $\mathrm{Nb}^{5+}$ sites. Furthermore, powder X-ray investigation for $\mathrm{NdNb}_{7} \mathrm{O}_{19}$ and $\mathrm{PrNb}_{7} \mathrm{O}_{19}$ were reported and the structural information is provided in Table S3 in the supporting information $[46,58]$.

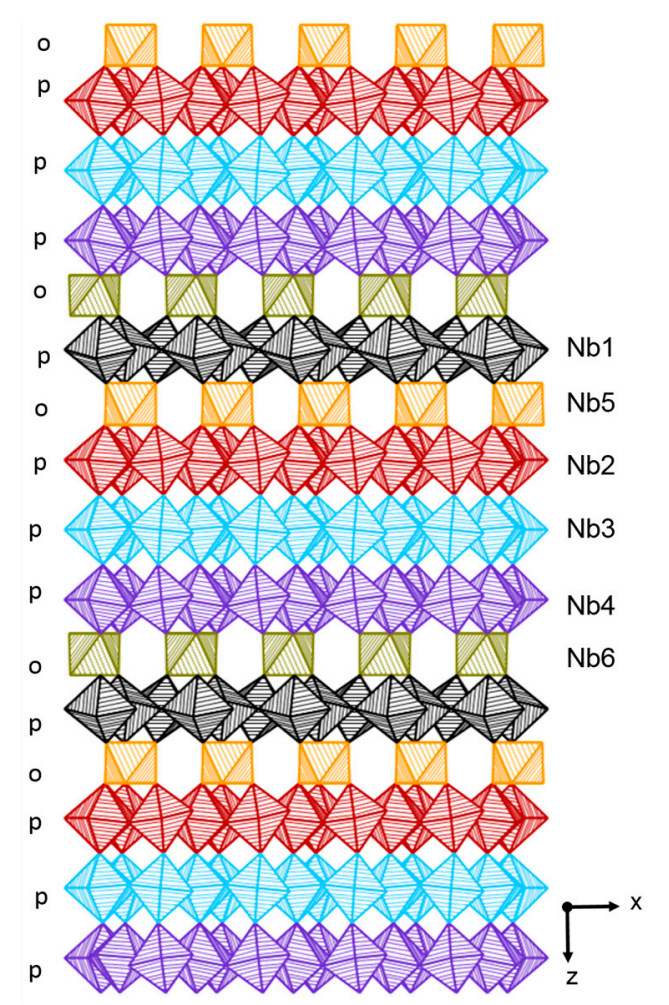

Figure 4. The crystal structure $\mathrm{LaNb}_{7} \mathrm{O}_{19}$, with labels for the symmetry inequivalent $\mathrm{Nb}$ cations in each layer. The layers of $\mathrm{NbO}_{7}$ pentagonal bipyramids are shown in black $(\mathrm{Nb} 1)$, red $(\mathrm{Nb} 2)$, blue $(\mathrm{Nb} 3)$, and purple $(\mathrm{Nb} 4)$ stripped polyhedra. The $\mathrm{NbO}_{6}$ octahedra are shown in orange $(\mathrm{Nb} 5)$ and gold $(\mathrm{Nb} 6)$ striped polyhedra.

\section{Structural Distortion and Polymorphism}

Symmetry-lowering distortions have been observed for several of the $\mathrm{Nb}$ - and Ta-containing structures constructed with $\alpha-\mathrm{U}_{3} \mathrm{O}_{8}$ type pentagonal bipyramid layers. For example, structures composed of single $\mathrm{MO}_{7}$ pentagonal bipyramid layers (e.g., $\mathrm{Ag}_{2} \mathrm{Nb}_{4} \mathrm{O}_{11}, \mathrm{Cu}_{2} \mathrm{Ta}_{4} \mathrm{O}_{11}, \mathrm{Na}_{2} \mathrm{Nb}_{4} \mathrm{O}_{11}$, 
$\mathrm{PbTa}_{4} \mathrm{O}_{11}$ ) have exhibited structural distortions under various conditions (e.g., as a function of temperature, composition, etc.). Second-order Jahn-Teller (SOJT) effects by $\mathrm{d}^{0}$ cations in octahedral coordination environments can be the driving force for structural distortions and symmetry lowering transitions, such as leading to noncentrosymmetric structures [59]. The SOJT distortions have typically been found for octahedral $\mathrm{d}^{0}$ cations with high valency, with the magnitude of the distortion increasing in the following order: $\mathrm{Zr}^{4+}<\mathrm{Ta}^{5+}<\mathrm{Nb}^{5+}<\mathrm{W}^{6+}<\mathrm{V}^{5+}<\mathrm{Mo}^{6+}$ [59]. The magnitude of the distortions are expected to increase as the energy separation between the metal-based $t_{2 g} d$-orbitals and the non-bonding $\mathrm{O} 2 \mathrm{p}$ states decrease, owing to a greater mixing of the occupied ( $\mathrm{O}$ based) and unoccupied ( $\mathrm{M}$ based) crystal orbitals [60]. Another theory described by Kunz and Brown finds that the directions of the displacements of the $\mathrm{d}^{0}$ cations are not primarily determined from the electronic SOJT effect [61], but rather the cation displacement is influenced more by bond network stresses (e.g., asymmetry in the bond network from the nearest neighbors). In addition, cation-cation repulsions from near-neighbor cations that share edges or faces also increase bond network stresses.

\subsection{Niobates}

Symmetry lowering transitions that are a function of temperature have only been reported for the niobium-containing structures $\mathrm{Ag}_{2} \mathrm{Nb}_{4} \mathrm{O}_{11}$ and $\mathrm{Na}_{2} \mathrm{Nb}_{4} \mathrm{O}_{11}$ [42,43]. The $\mathrm{Ag}_{2} \mathrm{Nb}_{4} \mathrm{O}_{11}$ phase transforms from the centrosymmetric $R \overline{3} c$ space group to the noncentrosymmetric R3c space group upon cooling to $\approx 127^{\circ} \mathrm{C}$. The driving force of this symmetry-lowering transition has been described to arise from the displacement of $\mathrm{Ag}$ and $\mathrm{Nb}$ cations within the pentagonal bipyramid and the octahedral layers [43]. The $\mathrm{Ag}$ and $\mathrm{Nb}$ cations are shifted out of the center of the polyhedra towards the octahedral faces of the distorted $\mathrm{MO}_{6}(\mathrm{M}=\mathrm{Ag}, \mathrm{Nb})$ polyhedra, yielding a dipole moment along the $c$ axis [43]. The $\mathrm{Nb}^{5+}$ cations in pentagonal bipyramidal layers are displaced towards the apical $\mathrm{O}$ atoms in the polyhedra [43]. A second symmetry-lowering transition into the R3 space group is observed upon cooling to $-73^{\circ} \mathrm{C}$ and has been attributed to shifts in the equatorial $\mathrm{O}$ atoms of the $\mathrm{NbO}_{7}$ pentagonal bipyramids are found to occur [43].

By comparison, the symmetry lowering distortions of $\mathrm{Na}_{2} \mathrm{Nb}_{4} \mathrm{O}_{11}$ from $R \overline{3} c$ to $\mathrm{C} 2 / \mathrm{c}$ upon cooling to $\approx 107^{\circ} \mathrm{C}$ yields a nonpolar centrosymmetric structure [43,62]. The structural relationship of the phase transformation between the monoclinic and hexagonal-rhombohedral unit cells has been previously described $[42,63]$. The origin of the structural distortion is primarily related to the displacement of the $\mathrm{Nb}$ cation within the plane of the pentagonal bipyramidal layer [42]. Below the transition temperature, two crystallographically distinct $\mathrm{Nb}$ cations, (i.e., $\mathrm{Nb} 1$ and $\mathrm{Nb} 2$ ) are generated in the pentagonal bipyramidal layer [42]. The longest interatomic distance between Nb1-O4 increases, causing its polyhedron to further distort in the layer, while the $\mathrm{Nb} 2$ polyhedron becomes a more regular pentagonal bipyramid [42].

\subsection{Tantalates}

\subsection{1. $\mathrm{Cu}_{2} \mathrm{Ta}_{4} \mathrm{O}_{11}$}

The $\mathrm{Cu}_{2} \mathrm{Ta}_{4} \mathrm{O}_{11}$ structure occurs in two polymorphs, namely, the monoclinic $\alpha-\mathrm{Cu}_{2} \mathrm{Ta}_{4} \mathrm{O}_{11}$ phase and the rhombohedral $\beta-\mathrm{Cu}_{2} \mathrm{Ta}_{4} \mathrm{O}_{11}[64,65]$, shown in Figures 5 and 6 . At temperatures of $-50{ }^{\circ} \mathrm{C}$ to room temperature, the monoclinic $\alpha-\mathrm{Cu}_{2} \mathrm{Ta}_{4} \mathrm{O}_{11}$ phase is relatively stable. The rhombohedral $\beta-\mathrm{Cu}_{2} \mathrm{Ta}_{4} \mathrm{O}_{11}$ phase emerges upon heating the monoclinic $\alpha-\mathrm{Cu}_{2} \mathrm{Ta}_{4} \mathrm{O}_{11}$ phase to between $250{ }^{\circ} \mathrm{C}$ and $550^{\circ} \mathrm{C}$ [64]. This symmetry-lowering distortion is driven by the edge-shared Ta $\mathrm{d}^{0}$ cations that form the single pentagonal bipyramidal layers [64]. The direction of the out-of-center displacement of the Ta cations are towards the vertices of the polyhedra not shared by neighboring Ta cations, as illustrated in Figures 5 and 6 for the distorted and non-distorted structures, respectively [64]. Thus, it appears that the repulsion from nearest-neighbor cations directs the out-of-center displacement of Ta $\mathrm{d}^{0}$ cations towards an edge of the polyhedron that is not shared by a neighboring Ta cation within the layer [64]. The longer interatomic distance between Ta2-O2 in the pentagonal bipyramidal 
layer increases from $2.44 \AA$ to $2.55 \AA$; thus, the Ta2 cation, coordinated to $7 \mathrm{O}$ atoms in a pentagonal bipyramid, is transformed into a highly-distorted $\mathrm{TaO}_{6}$ octahedron within the tantalate layer [64].
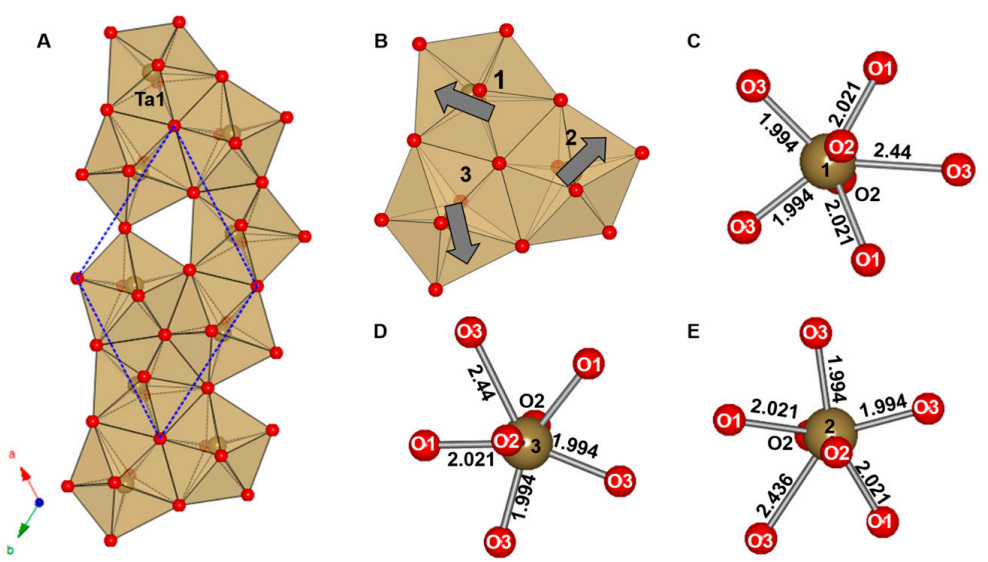

Figure 5. The crystal structure of a single edge-sharing $\mathrm{TaO}_{7}$ pentagonal bipyramid layer of the rhombohedral $\beta-\mathrm{Cu}_{2} \mathrm{Ta}_{4} \mathrm{O}_{11}(\mathrm{~A})$ a view of the edge sharing of Ta cations along the $a b$ plane with the unit cell outline as a blue dashed line (B) a smaller segment from the uppermost three Ta cations, where the grey arrows indicate the out-of-center displacement of Ta; and (C-E) local views of the coordination environments of the Ta cations labeled 1, 2, and 3, respectively. Reproduced with permission from [64], published by Elsevier, 2014.

A

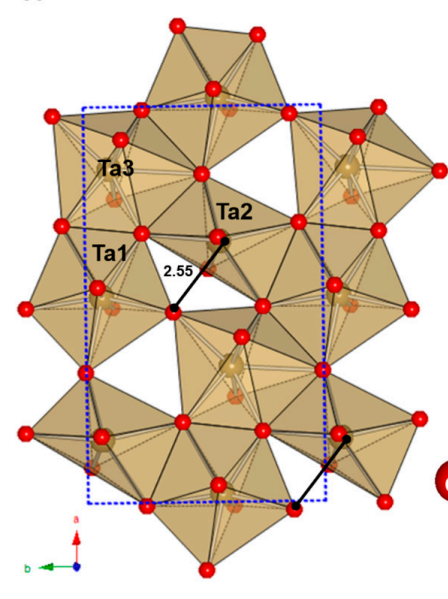

B

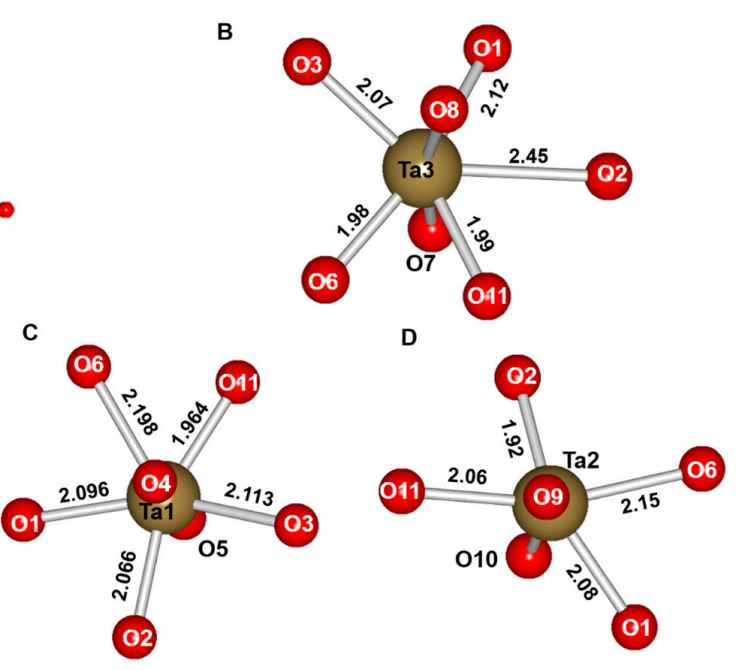

D

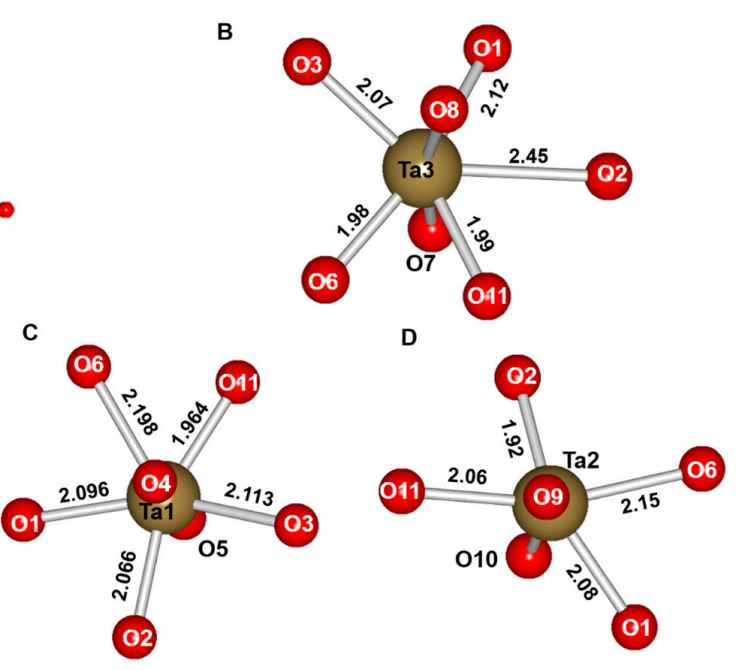

Figure 6. (A) Polyhedral view of a layer of edge-sharing $\mathrm{TaO}_{7}$ pentagonal bipyramids in the monoclinic $\alpha-\mathrm{Cu}_{2} \mathrm{Ta}_{4} \mathrm{O}_{11}$, with the unit cell outline as a blue dashed line and the black line indicating the distortion of Ta2 into an octahedron; and (B-D) the local coordination environment of Ta3, Ta1, and Ta2, respectively. Reproduced with permission from [64], published by Elsevier, 2014.

An explanation of the phase transition observed in the rhombohedral $\beta-\mathrm{Cu}_{2} \mathrm{Ta}_{4} \mathrm{O}_{11}$ can be suggested from bond length arguments. The longer Ta-O interatomic distances observed in the $\mathrm{TaO}_{6}$ and $\mathrm{TaO}_{7}$ polyhedra in $\mathrm{Cu}_{2} \mathrm{Ta}_{4} \mathrm{O}_{11}$ are comparable to the $\mathrm{Nb}-\mathrm{O}$ distances in $\mathrm{Na}_{2} \mathrm{Nb}_{4} \mathrm{O}_{11}$ and $\mathrm{Ag}_{2} \mathrm{Nb}_{4} \mathrm{O}_{11}$. Thus, these polyhedra are more flexible to accommodate an out-of-center displacement of the $\mathrm{Ta} / \mathrm{Nb}$ cations. In the rhombohedral $\beta-\mathrm{Cu}_{2} \mathrm{Ta}_{4} \mathrm{O}_{11}$ structure, effects from cation-cation repulsion likely cause the nearest neighbor Ta $5 \mathrm{~d}^{0}$ cations within three edge-shared $\mathrm{TaO}_{7}$ polyhedra to move out of the center of the polyhedra. $\mathrm{The}_{\mathrm{TaO}}$ pentagonal bipyramid layer distorts into a layer containing $\mathrm{TaO}_{6}$ and $\mathrm{TaO}_{7}$ polyhedra, where $\mathrm{Ta} 3$ and $\mathrm{Ta} 1$ maintain the $\mathrm{TaO}_{7}$ pentagonal bipyramid coordination environment and Ta2 centers a highly-distorted $\mathrm{TaO}_{6}$ octahedron [64]. The monoclinic $\alpha-\mathrm{Cu}_{2} \mathrm{Ta}_{4} \mathrm{O}_{11}$ 
structure contains fewer edges that are shared as the Ta2-O2 interatomic distance lengthens to $\approx 2.55(3) \AA$, an increase of $\approx 0.13 \AA$ as compared to the rhombohedral $\beta-\mathrm{Cu}_{2} \mathrm{Ta}_{4} \mathrm{O}_{11}$ structure [64]. Structural distortions to lower symmetry have not been observed for $\mathrm{Ag}_{2} \mathrm{Ta}_{4} \mathrm{O}_{11}$, which could be due to the slightly larger interatomic distances in the equatorial plane of edge-shared pentagonal bipyramids for Ta1-O3 in $\mathrm{Cu}_{2} \mathrm{Ta}_{4} \mathrm{O}_{11}$ as compared to those in $\mathrm{Ag}_{2} \mathrm{Ta}_{4} \mathrm{O}_{11}$, at 2.45(8) $\AA$ and 2.398(2) $\AA$, respectively [43]. The $\mathrm{TaO}_{6}$ octahedron are also relatively larger, in the range of 1.92(7) $\AA-2.20(6) \AA$, as compared to those in $\mathrm{Ag}_{2} \mathrm{Ta}_{4} \mathrm{O}_{11}$ at 1.9845(5) $\AA$ [43].

\subsection{2. $\mathrm{PbTa}_{4} \mathrm{O}_{11}$}

Comparable to that described above for $\mathrm{Cu}_{2} \mathrm{Ta}_{4} \mathrm{O}_{11}$, distortions were observed for PbTa4O11 when it was prepared from $\mathrm{Ag} 2 \mathrm{Ta} 4 \mathrm{O} 11$ by a $\mathrm{Pb}$-ion exchange reaction. Similar to the parent structure of $\mathrm{Ag}_{2} \mathrm{Ta}_{4} \mathrm{O}_{11}(\mathrm{R} \overline{3} \mathrm{c})$, the lower-symmetry $\mathrm{PbTa}_{4} \mathrm{O}_{11}$ (R3) exhibits two symmetry-unique layers of edge-shared $\mathrm{TaO}_{7}$ pentagonal bipyramids ( $\mathrm{Ta} 1$ and $\mathrm{Ta} 2$ ), layers of $\mathrm{TaO}_{6}$ octahedra ( $\mathrm{Ta} 3$ and $\mathrm{Ta} 4$ ), and $\mathrm{Pb}(\mathrm{II})$ cations ( $\mathrm{Pb} 1$ and $\mathrm{Pb} 2)$, as shown in Figure 7 [35]. Each of the isolated $\mathrm{TaO}_{6}$ octahedra is surrounded by three monocapped trigonal prismatic $\mathrm{PbO}_{7}$ polyhedron that alternate in their orientation, (i.e., [001] for $\mathrm{Pb} 1$ and [001] for $\mathrm{Pb} 2$ ) [35]. The $\mathrm{PbO}_{7}$ polyhedra are formed by six apical $\mathrm{O}$ atoms and one equatorial $\mathrm{O}$ atom $(\mathrm{Pb} 1-\mathrm{O} 7, \mathrm{~Pb} 2-\mathrm{O} 9)$ from the adjacent $\mathrm{TaO}_{7}$ layers that result in the asymmetric coordination environment [35]. Divalent $\mathrm{Pb}$ cations commonly undergo intra-polyhedral distortions due to their high degree of polarizability and their stereoactive electron lone pair, and thereby adopt stable asymmetric anion coordination environments (i.e., $\mathrm{PbO}_{7}$ ) [59,61,66-68]. The stabilization of the $\mathrm{Pb}(\mathrm{II})$ cations results in their displacement towards the $\mathrm{Ta}(\mathrm{V})$ cations, which in turn electrostatically repulses the $\mathrm{Ta}$ atoms ( $\mathrm{Ta} 1$ and $\mathrm{Ta} 2$ ) from the center of their $\mathrm{TaO}_{7}$ polyhedra towards their apical $\mathrm{O}$ atoms [35]. Similarly, the $\mathrm{Ta}$ atoms in the $\mathrm{TaO}_{6}$ octahedra were displaced towards the octahedral faces away from the $\mathrm{Pb}$ (II) cations, analogous to the polar distortions reported for $\mathrm{Ag}_{2} \mathrm{Nb}_{4} \mathrm{O}_{11}$ (R3) [43]. Displacement of the $\mathrm{Ta}(\mathrm{V})$ and the $\mathrm{Pb}(\mathrm{II})$ cations along the c-axis culminated in alternating expanded and contracted $\mathrm{TaO}_{7}$ pentagonal bipyramidal interlayer distances [35].

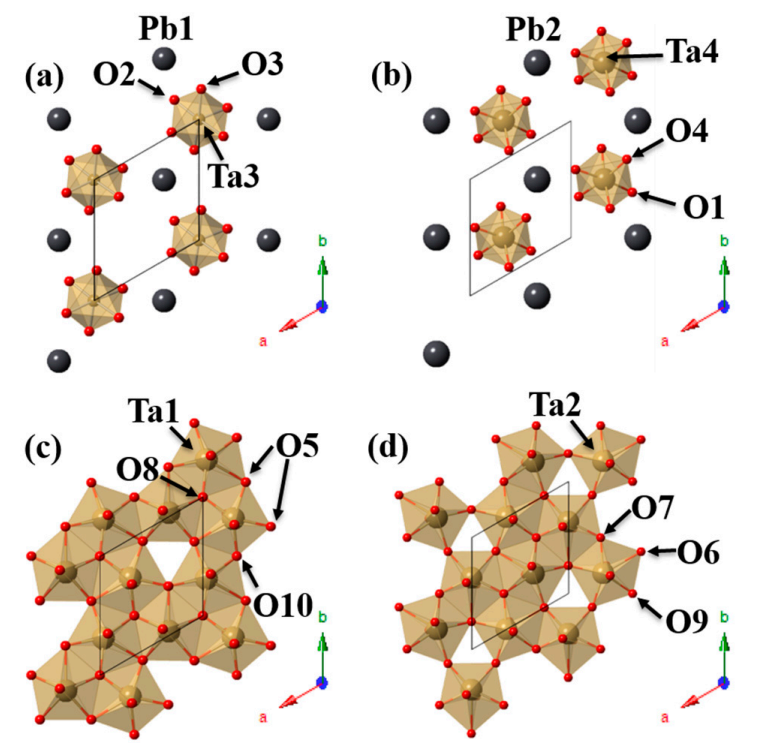

Figure 7. Polyhedral view of the four symmetry-unique layers of $\mathrm{PbTa}_{4} \mathrm{O}_{11}$ that are composed of alternating layers of $(\mathbf{a}-\mathbf{b})$ isolated $\mathrm{TaO}_{6}$ octahedra surrounded by $\mathrm{Pb}(\mathrm{II})$ cations and (c-d) edge-sharing $\mathrm{TaO}_{7}$ pentagonal bipyramid layers. The unit cell is outlined in black with tan-colored $\mathrm{TaO}_{6}$ and $\mathrm{TaO}_{7}$ polyhedra, gray spheres for $\mathrm{Pb}$, and red spheres for oxygen. Reproduced with permission from [35], published by Elsevier, 2015. 
Similar to the distortions along the c-axis between adjacent tantalate layers, electrostatic repulsion effects within the $a b$ plane bring about two symmetry unique $\mathrm{TaO}_{7}$ pentagonal bipyramid layers. The off-center displacement of the nearest-neighbor Ta atoms (Ta1 and Ta2) towards empty trigonal cavities within the $\mathrm{TaO}_{7}$ layers relieves electrostatic strain caused by cation-cation repulsions. This resulted in two symmetry unique Ta atoms, six different Ta-O equatorial bond distances, and increased the $\mathrm{TaO}_{7}-\mathrm{TaO}_{7}$ nearest-neighbor distances, as shown in Figure 8 [35]. In comparison to the centrosymmetric $\mathrm{Ag}_{2} \mathrm{Ta}_{4} \mathrm{O}_{11}$ structure, the $\mathrm{TaO}_{7}$ layers are comprised of one symmetry unique $\mathrm{Ta}$, two different Ta-O equatorial bond distances, and shorter $\mathrm{TaO}_{7}-\mathrm{TaO}_{7}$ nearest-neighbor distances [43]. The symmetry-lowering polar distortions from the centrosymmetric $\mathrm{Ag}_{2} \mathrm{Ta}_{4} \mathrm{O}_{11} R \overline{3} c$ ) to the noncentrosymmetric $\mathrm{PbTa}_{4} \mathrm{O}_{11}(R 3)$ space group are characteristic of SOJT distortions that are typically observed for structures with high valent $\mathrm{d}^{0}$ cations (i.e., $\mathrm{Ta}(\mathrm{V})$ ) and cations containing filled valence s shells (i.e., $\mathrm{Pb}(\mathrm{II})$ ). The SOJT distortion reduces the crystal symmetry and is the driving force for stabilizing ionic shifts $[59,61,66-68]$.
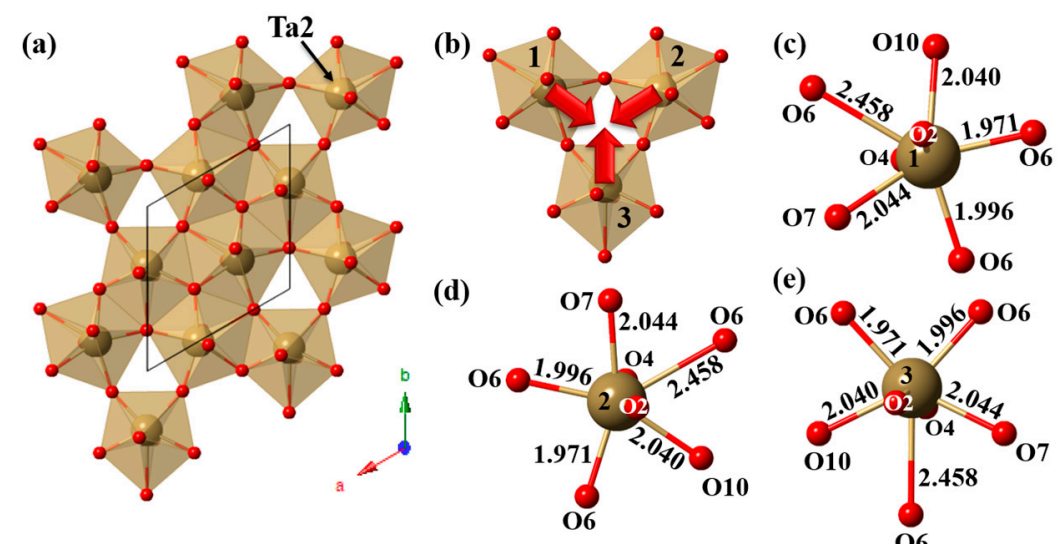

(e)

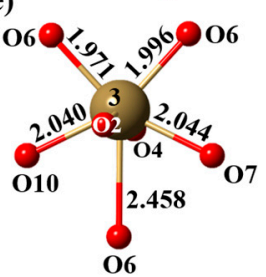

Figure 8. Polyhedral view and local coordination environments of one layer of $\mathrm{PbTa}_{4} \mathrm{O}_{11}$. Shown are (a) a polyhedral view of the $\mathrm{TaO}_{7}$ layer along the $a b$ plane with the unit cell outline in black; (b) a smaller segment from the lower right cluster of three labeled Ta2 atoms, with red arrows indicating the atomic displacement; and (c-e) the local coordination of the labeled Ta2 atoms. Reproduced with permission from [35], published by Elsevier, 2015.

\subsection{Niobates/Tantalates Solid Solution}

The polymorphism of the $\left(\mathrm{Na}_{1-x} \mathrm{Ag}_{x}\right)_{2} \mathrm{Nb}_{4} \mathrm{O}_{11}$ solid solutions have been investigated as a function of chemical composition and temperature by the Woodward and West groups, which revealed a complex system with interesting structural transformations $[69,70]$. The $\left(\mathrm{Na}_{1-x} \mathrm{Ag}_{x}\right)_{2} \mathrm{Nb}_{4} \mathrm{O}_{11}$ structures were characterized using Rietveld refinements of variable temperature powder X-ray and neutron diffraction data, differential scanning calorimetry, and lattice parameter trends. The West group reported a monoclinic $(C 2 / c)$ to rhombohedral $(R \overline{3} c)$ phase transformation upon heating compositions with $x \leq 0.25$, and a monoclinic $C 2 / c(x=0.25)$ to rhombohedral $R \overline{3} c$ phase transformation upon cooling below $\approx 107^{\circ} \mathrm{C}$. Further, the rhombohedral and monoclinic phases coexist in a two-phase region at the phase boundary for compositions of $0.65 \leq x \leq 0.8$. The origin of the rhombohedral $R \overline{3} c$ to monoclinic $\mathrm{C} 2 / \mathrm{c}$ phase transition is related to distortions within the equatorial plane of the $\mathrm{NbO}_{7}$ pentagonal bipyramids, as described below $[69,70]$.

An interesting series of ferroelectric-paraelectric phase transformations was observed using variable temperature powder $\mathrm{X}$-ray diffraction and lattice refinements. The transformation from $R 3$ to $R 3 c$ to $R \overline{3} c$ occurred upon heating to higher temperatures for compositions where $x \geq 0.85$. For example, upon cooling the $R \overline{3} \mathrm{c}$ phase $(x=0.875)$ it transforms to $R 3 \mathrm{c}$ at $\approx 87^{\circ} \mathrm{C}$ and to $R 3$ at $\approx-63^{\circ} \mathrm{C}$. The series of ferroelectric-paraelectric phase transformations are related to the displacement of the $\mathrm{Nb}$ atoms in the $\mathrm{NbO}_{7}$ pentagonal bipyramids towards the apical $\mathrm{O}$ atoms, as well as displacement of $\mathrm{Nb}$ 
atoms in $\mathrm{NbO}_{6}$ and $\mathrm{Na} / \mathrm{Ag}$ atoms towards their octahedral faces. A triclinic $P \overline{1}$ crystal structure was observed in the compositional range of $0.25<x<0.60$ in the temperature range $-273^{\circ} \mathrm{C}$ to $3{ }^{\circ} \mathrm{C}[70]$. Heating the low-temperature $P \overline{1}$ crystal structure resulted in the structural transformation to the monoclinic $\mathrm{P} 2_{1} / \mathrm{c}$ at temperatures up to room temperature. At temperatures above room temperature the monoclinic $\mathrm{P} 2{ }_{1} / \mathrm{c}$ crystal structure transforms to the rhombohedral $R \overline{3} c$ crystal structure [70]. The triclinic distortions from the rhombohedral structure are the result of a combination of off-center displacement of the $\mathrm{Nb}$ atoms in the $\mathrm{NbO}_{7}$ and $\mathrm{NbO}_{6}$ polyhedra, as well as movement of the equatorial $\mathrm{O}$ atoms in the $\mathrm{NbO}_{7}$ pentagonal bipyramid layers out of the equatorial plane [70].

The $\mathrm{Na}_{2-x} \mathrm{Cu}_{x} \mathrm{Ta}_{4} \mathrm{O}_{11}$ solid solutions were also investigated by the Maggard group with compositional limits between $0 \leq x \leq 0.78$ at a reaction temperature of $950{ }^{\circ} \mathrm{C}$ [71]. The solid solutions did not display any phase transformation; however, Wyckoff site substitution of $\mathrm{Na}$ cations and $\mathrm{Cu}$ cations in the $R \overline{3} c$ crystal structure of the solid solution were observed together with a significant decrease in bandgap size from $\approx 4.0 \mathrm{eV}$ to $\approx 2.65 \mathrm{eV}$ [71]. The origin of the differential site occupancy of the $\mathrm{Ag}$ and $\mathrm{Cu}$ cations is driven by the preferred coordination number of the $\mathrm{Na} / \mathrm{Cu}$ cation to the surrounding $\mathrm{O}$ atoms [71]. The linearly coordinated $\mathrm{Cu}$ cation and 7-coordinate $\mathrm{Na}$ cation are located at the 18d and 12c Wyckoff crystallographic sites, respectively. By comparison, the use of nanoparticle reactants and lower reaction temperatures of $\approx 625^{\circ} \mathrm{C}$ to $\approx 700{ }^{\circ} \mathrm{C}$ were found necessary to obtain the $\mathrm{Cu}$-richest composition, i.e., $\mathrm{Cu}_{2} \mathrm{Ta}_{4} \mathrm{O}_{11}$, in high crystalline purity[65]. This composition was found to undergo a transformation from a monoclinic structure $(C c)$ to a rhombohedral $(R \overline{3} c)$ crystal structure upon heating, i.e., from $\alpha-\mathrm{Cu}_{2} \mathrm{Ta}_{4} \mathrm{O}_{11}$ to $\beta-\mathrm{Cu}_{2} \mathrm{Ta}_{4} \mathrm{O}_{11}$, as described above [64].

\section{Photocatalysis}

\subsection{Background}

Among renewable energy sources, solar energy is the largest, exploitable resource that could meet current and future human energy demand, with an estimation that $\approx 0.015 \%$ of solar energy reaching the earth would be enough to support human civilization [72-75]. The capture and conversion of solar energy to drive photocatalytic hydrogen production would provide a clean alternative energy solution that can be used to generate useful chemical fuels Honda and Fujishima were the first to demonstrate the decomposition of $\mathrm{H}_{2} \mathrm{O}$ into $\mathrm{H}_{2}$ and $\mathrm{O}_{2}$ using $\mathrm{TiO}_{2}$ as an $n$-type photocatalyst [76]. Since this groundbreaking work, semiconductor-based photocatalytic water splitting to produce hydrogen has been considered one of the most important approaches to solving the world energy crisis [77]. Semiconductors have also been used in practical application for the photocatalytic degradation of organic pollutants in water [78-81]. The photoelectrolysis of water using semiconductors as both light absorber and energy converter (i.e., catalyst) to store the solar energy in the simplest bond, $\mathrm{H}_{2}$, has been described as the "Holy Grail" of solar energy conversion and storage [74,82-84].

Photocatalysis for water splitting can be divided into four mechanistic steps: (a) absorption of photons to excite electrons from the valence band to the conduction band; (b) charge separation electrons and holes; (c) diffusion of the photoexcited electrons and holes to the surfaces as driven by the space-charge layer, and (d) surface chemical reactions between the charge carriers and the adsorbates [85-89]. The illustration in Figure 9 shows a photocatalyst particulate and the four basic steps, where (d) also includes the competing volume and surface recombination processes. An efficient photocatalyst must have band gap energies capable of the absorption of visible light energies and possess energetic band positions suitable for driving water reduction and oxidation reactions (i.e., $\mathrm{E}_{\mathrm{g}} \geq 1.23 \mathrm{eV}$ ) [90]. The valence and conduction band energies of several semiconductors are plotted in Figure 10, and shown relative to the water redox couples for water splitting. Additionally, the photocatalyst must be stable in aqueous solution under solar irradiation. The use of co-catalysts on semiconductors has proven to be an effective approach to promote charge separation, transfer, and to suppress recombination and back-reactions during photocatalysis [91]. The electronic structure of the semiconductor also determines the functionality and efficiency of a photocatalyst. This is not 
limited to the space charge width alone, which is composed of the accumulation layer, depletion layers, and inversion layer. The carrier diffusion lengths, and charge carrier mobility are also critical to the material's photocatalytic performance [85,92-95]. In addition, selecting a suitable doping strategy is essential to enhancing photocatalytic properties [96]. Common challenges for achieving water splitting with heterogeneous photocatalysts include rapid recombination of electrons/holes [97], hole/electron collection at particle surfaces [98], and improvement of the photocatalytic rates [99,100].

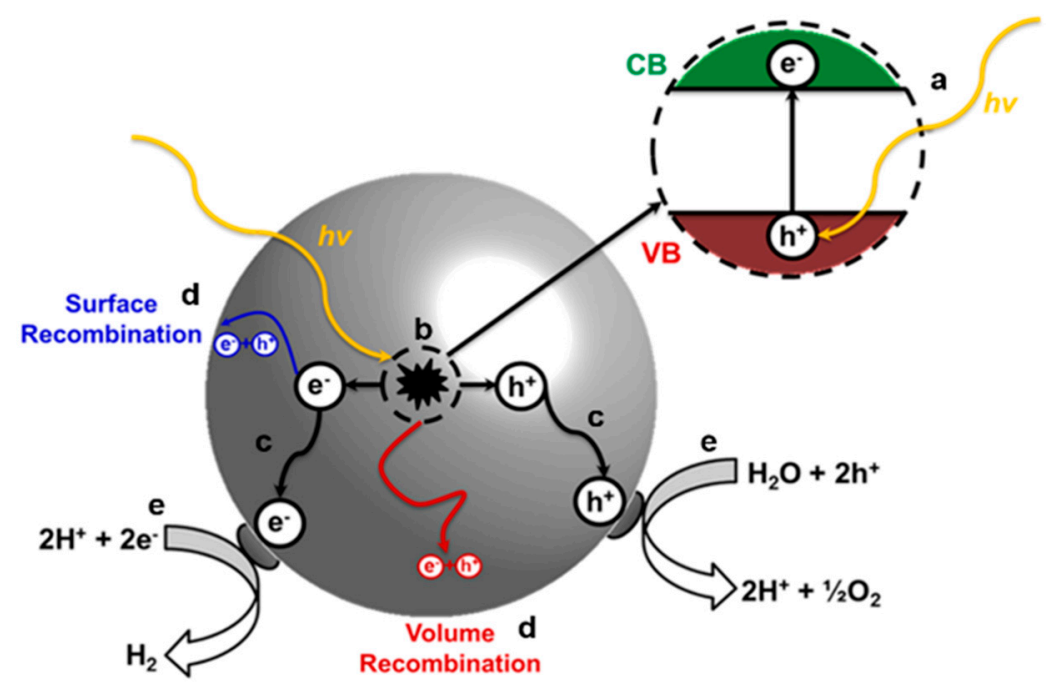

Figure 9. An illustration of a particulate photocatalyst, showing the processes of (a) light absorption; (b) charge separation; (c) charge migration; (d) recombination; and (e) redox reaction.

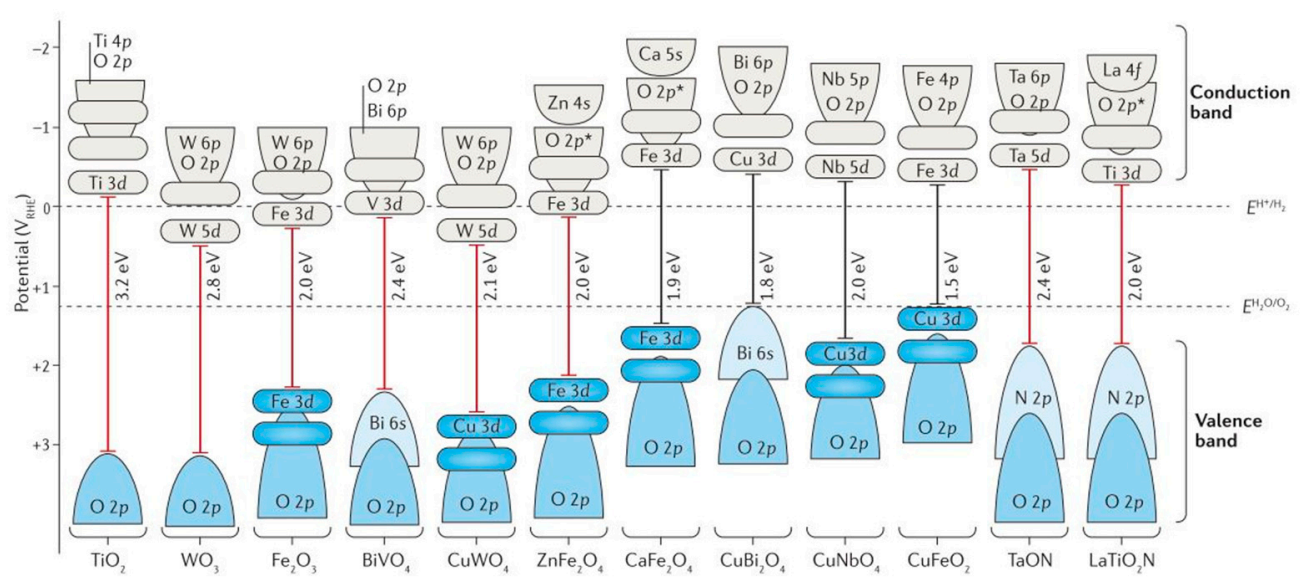

Figure 10. The bandgap energies (red for $n$-type, black for $p$-type) are shown with respect to the reversible hydrogen electrode and the water oxidation redox couple (assuming Nernstian behavior for the band-edge energies with respect to the electrolyte $\mathrm{pH}$ ). The contribution of the valence and conduction band orbitals are outlined in blue and grey, respectively. Reproduced with permission from [101], published by Macmillian Publishers Limited, Part of Springer Nature, 2016.

Evaluation of photocatalysts under experimental conditions suitable for water splitting is dependent upon the following: the evolution of $\mathrm{O}_{2}$ and $\mathrm{H}_{2}$ gases, stability over time, as a function of wavelength (i.e., ultraviolet or visible light), and overall efficiency of the system [101-105]. Depending upon the overall configuration of the photocatalytic measurements, (i.e., whether in the form of 
suspended particles or as a polycrystalline film) various parameters are important to assess solar-to-fuel energy conversion, including the photocurrent density, turnover frequency, overall quantum yield,

$$
\text { Overall Quantum Yield }=\frac{\text { rate of reaction }}{\text { rate of absorption of radiation }}=\frac{N_{\text {mol }}}{N_{p h}}
$$

and the incident photon-to-current-efficiency (IPCE). The photoelectrochemical properties of polycrystalline films of the $\mathrm{Cu}(\mathrm{I})$ tantalates of this structural family (e.g., $\mathrm{Cu}_{5} \mathrm{Ta}_{11} \mathrm{O}_{30}$ ) have been recently reviewed [85], and this current review will focus on their photocatalytic activity as suspended powders in aqueous solutions.

For investigations where solid photocatalysts particles are suspended in an aqueous solution and irradiated, the rate of hydrogen and/or oxygen production and the quantum yield are commonly reported. A turnover number can be calculated from the moles of evolved $\mathrm{H}_{2}$ and the number of surface active sites of the photocatalyst. The latter can be approximated from surface area measurements and a knowledge of the crystalline structure, and this is typically reported in units of $\mu \mathrm{mol} \cdot \mathrm{h}^{-1} \cdot \mathrm{g}^{-1}$. The overall quantum yield, listed in Equation (1), is defined as the number of molecules produced relative to the total number of incident photons in a reaction vessel [83]. The number of molecules $\mathrm{N}_{\text {mol }}$ undergoing an event (conversion of reactants or formation of products) relative to the number of quanta (photons) $\mathrm{N}_{\text {ph }}$ absorbed by the reactants or photocatalyst is determined based on the $\mathrm{cm}^{3}$ per seconds $\left(\mathrm{cm}^{3} / \mathrm{s}\right)$ of the reactions.

Heterogeneous photocatalysts for water reduction or oxidation are common among many metal-oxide systems, which include binary oxides (i.e., $\mathrm{TiO}_{2}, \mathrm{Cu}_{2} \mathrm{O}, \mathrm{Fe}_{2} \mathrm{O}_{3}, \mathrm{WO}_{3}$ ), oxynitride systems (i.e., $\mathrm{TaO}_{x} \mathrm{~N}_{\mathrm{y}} \mathrm{BaTaO}_{2} \mathrm{~N}$, $\left.\mathrm{LaTiO}_{2} \mathrm{~N}\right)$, layered oxides $\left(\mathrm{K}_{4} \mathrm{Nb}_{6} \mathrm{O}_{17}, \mathrm{Na}_{2} \mathrm{~W}_{4} \mathrm{O}_{13}, \mathrm{RbLaNb}_{2} \mathrm{O}_{7}\right)$, and mixed-metal oxides $\left(\mathrm{BiVO}_{4}, \mathrm{CuFeO}_{2}, \mathrm{CuWO}_{4}\right)$ [106-113]. In addition perovskite-based photocatalysts have been extensively studied and various strategies have been employed for enhancing photocatalytic performance $[90,114,115]$. The use of mixed-metal compositions is critical to lowering the bandgap sizes of simpler metal oxides into the visible region [116]. Layered oxide systems are also of importance in photocatalytic systems due to their unique interlayer spaces in which reduction sites are separated from oxidation sites, yielding among the highest rates for hydrogen and oxygen production from solar energy [117-119]. However, the incorporation of secondary transition metals into the interlayer sites, (i.e., to lower their bandgap sizes into the visible range) is typically not a stable configuration in aqueous solutions where the layers can delaminate. Thus, the family of layered structures based pentagonal bipyramid layers serve as an alternative for achieving efficient water splitting activity in aqueous solutions. In addition, several members within the system are comprised of early and late transitions metals (i.e., $\mathrm{Cu}^{1+} / \mathrm{Ta}^{5+}, \mathrm{Ag}^{1+} / \mathrm{Nb}^{5+}, \mathrm{Ag}^{1+} / \mathrm{Ta}^{5+}$ ) which possess lower visible-light band gaps that are suitable for use with the solar spectrum and capable of driving the water splitting reactions.

The Maggard group has extensively investigated the visible and ultraviolet photocatalytic activity of members from the $\mathrm{A}^{m+}{ }_{((n+1) / m)} \mathrm{B}_{(3 n+1)} \mathrm{O}_{(8 n+3)}$ (e.g., $\mathrm{A}=\mathrm{Na}, \mathrm{Ag}, \mathrm{Cu}, \mathrm{Pb}, \mathrm{Bi} ; \mathrm{B}=\mathrm{Nb}, \mathrm{Ta}$ ) family of structures as both suspended particles and polycrystalline films for water splitting $[92,116,120,121]$. Improved charge separation and photocatalytic/photoelectrochemical redox reactions have been proposed to be enhanced in these structures due to the preferential anisotropic diffusion of charge carriers along the $\mathrm{BO}_{7}$ pentagonal bipyramid layers. The anisotropic charge diffusion is a result of the delocalization of the $\mathrm{Nb} 4 \mathrm{~d}$ and the Ta $5 \mathrm{~d}$ lowest-energy unoccupied crystal orbitals across the $\mathrm{BO}_{7}$ pentagonal bipyramid layers, as confirmed by electronic structure calculations which show the largest band dispersion in these crystallographic directions $[35,47,64,65,71,122-128]$.

\subsection{Photocatalysts with Single $\mathrm{MO}_{7}$ Layers}

The first system investigated in this family of structures for photocatalytic activity was the natrotantite compound, $\mathrm{Na}_{2} \mathrm{Ta}_{4} \mathrm{O}_{11}$, which showed activity for hydrogen production under ultraviolet-visible light of $\approx 13.4$ to $\approx 34 \mu \mathrm{mol} \mathrm{H}_{2} \cdot \mathrm{h}^{-1} \cdot \mathrm{g}^{-1}$ [127]. Owing to its large bandgap size of $\approx 4.3 \mathrm{eV}$, its activity was limited to ultraviolet light wavelengths. The variation in $\mathrm{H}_{2}$ gas rates were 
dependent upon the synthetic conditions and the particle sizes and surface areas of the polycrystalline powders [127]. The particle sizes varied with a wide distribution from $\approx 100 \mathrm{~nm}$ to $>\approx 1000 \mathrm{~nm}$ among all of the products that were investigated by scanning electron microscopy, with low total surface areas from $\approx 0.8$ to $\approx 1.0 \mathrm{~m}^{2} / \mathrm{g}$. Notably, the highest photocatalytic rates for hydrogen production were found for crystallites with highly faceted and nanoterraced surfaces. These rates were stable over the course of several hours during the photocatalytic reactions [127]. Similarly, the Ag(I) analogues, i.e., $\mathrm{Ag}_{2} \mathrm{M}_{4} \mathrm{O}_{11}(\mathrm{~A}=\mathrm{Ta}, \mathrm{Nb})$, have been investigated as photocatalysts for water splitting and organic dye degradation [124,126,129]. The $\mathrm{Ag}_{2} \mathrm{Nb}_{4} \mathrm{O}_{11}$ composition has a smaller band gap of $\approx 3.1 \mathrm{eV}$, while for $\mathrm{Ag}_{2} \mathrm{Ta}_{4} \mathrm{O}_{11}$ it is $\approx 3.9 \mathrm{eV}$. As a suspended powder, the $\mathrm{Ag}_{2} \mathrm{Ta}_{4} \mathrm{O}_{11}$ compounds shows photocatalytic activity for hydrogen production of $\approx 23 \mu \mathrm{mol} \mathrm{H} \mathrm{H}_{2} \cdot \mathrm{h}^{-1} \cdot \mathrm{g}^{-1}$. This is similar in rate to that found for $\mathrm{Na}_{2} \mathrm{Ta}_{4} \mathrm{O}_{11}$. However, the activity for oxygen production was significantly higher $\approx 165 \mu \mathrm{mol} \mathrm{O} \mathrm{O}_{2} \cdot \mathrm{h}^{-1} \cdot \mathrm{g}^{-1}$, and higher compared to that for $\mathrm{Na}_{2} \mathrm{Ta}_{4} \mathrm{O}_{11}$ of $\approx 110 \mu \mathrm{mol} \mathrm{O}{ }_{2} \cdot \mathrm{h}^{-1} \cdot \mathrm{g}^{-1}$. Both compounds crystallize in the same centrosymmetric rhombohedral space group, which suggests the higher activity for oxygen production arises from the new Ag-based valence band in $\mathrm{Ag}_{2} \mathrm{Ta}_{4} \mathrm{O}_{11}$, shown in Figure 11. By comparison, the $\mathrm{Ag}_{2} \mathrm{Nb}_{4} \mathrm{O}_{11}$ compound is ferroelectric and crystallizes in the polar R3c space group at room temperature. While the $\mathrm{Ag}_{2} \mathrm{Nb}_{4} \mathrm{O}_{11}$ compound has been found active for photocatalytic dye degradation [129], there are currently no reports of its photocatalytic activity for water reduction or oxidation.

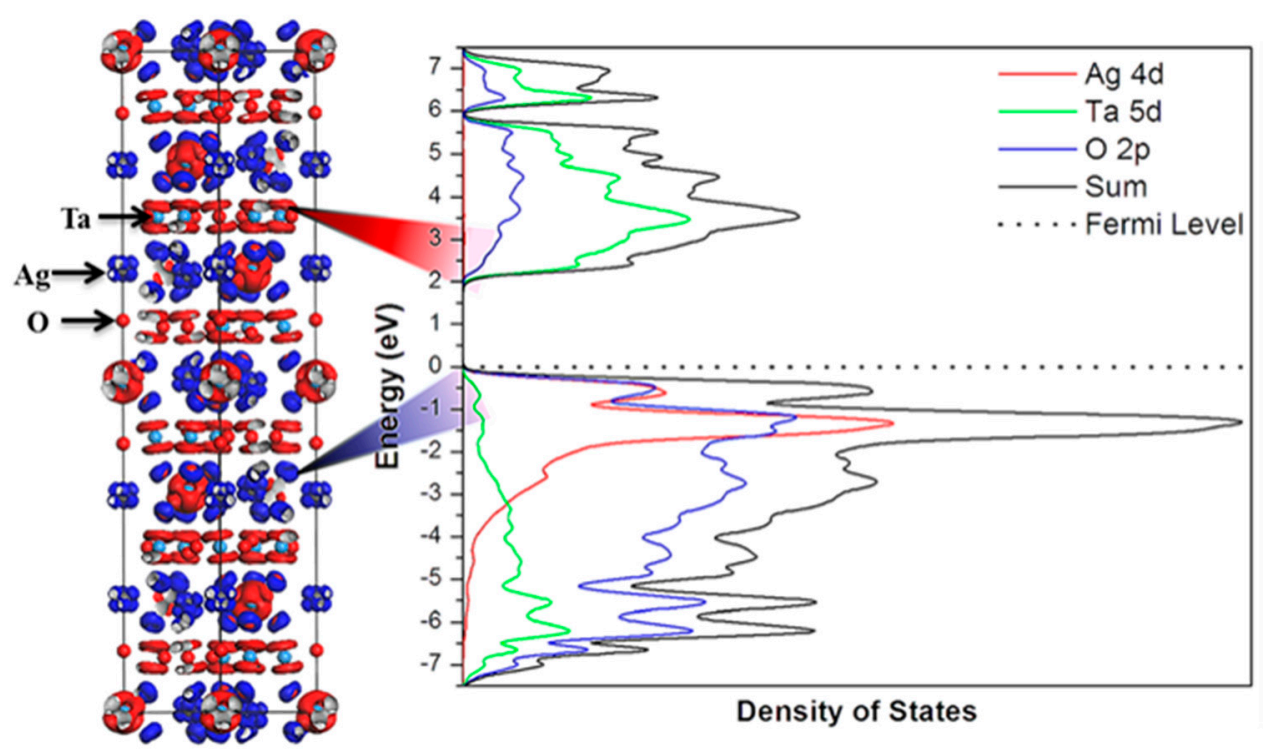

Figure 11. The densities-of-states (DOS; right) and electron density plots (left) of $\mathrm{Ag}_{2} \mathrm{Ta}_{4} \mathrm{O}_{11}$. The individual atomic contributions are projected out in the DOS, and the electron density at the top of the valence band and bottom of the conduction band are shaded red and blue, respectively. Reprinted with permission from [126]. Copyright 2013 American Chemical Society.

More recently, the solid solutions of $\mathrm{Na}_{2} \mathrm{Ta}_{4-} \mathrm{Nb}_{y} \mathrm{O}_{11}(1 \leq y \leq 4)$ were investigated for hydrogen production [125]. All solid solution compositions investigated were photocatalytically active for the generation of hydrogen and exhibited higher rates for hydrogen production in comparison to $\mathrm{Na}_{2} \mathrm{Ta}_{4} \mathrm{O}_{11}$ and $\mathrm{Ag}_{2} \mathrm{Ta}_{4} \mathrm{O}_{11}$ [125], as shown in Figure 12. Mott-Schottky measurements were evaluated in order to determine the positions of the conduction and valence band edges for selected samples in the $\mathrm{Na}_{2} \mathrm{Ta}_{4-y} \mathrm{Nb}_{y} \mathrm{O}_{11}$ solid solution. The conduction band energies followed a trend toward more positive potentials and resulted in a red-shift in the absorption edge owing to the increase in lower energy $\mathrm{Nb} 4 \mathrm{~d}$ orbitals [125]. The bandgap size decreased across the solid solution series from $\approx 4.3 \mathrm{eV}$ for $\mathrm{Na}_{2} \mathrm{Ta}_{4} \mathrm{O}_{11}$ to $\approx 3.6 \mathrm{eV}$ for $\mathrm{Na}_{2} \mathrm{Nb}_{4} \mathrm{O}_{11}$. The highest photocatalytic rate for hydrogen production was exhibited by $\mathrm{Na}_{2} \mathrm{Nb}_{4} \mathrm{O}_{11}$, which generated $84 \mu \mathrm{mol} \mathrm{H} \mathrm{H}_{2} \cdot \mathrm{h}^{-1} \cdot \mathrm{g}^{-1}$ under ultraviolet-visible light 
$(\lambda>230 \mathrm{~nm})$ [125]. At an $x \approx 2.7$ to 3.0, (i.e., $\approx 67 \%$ to $\approx 70 \% \mathrm{Nb}$ content) the structural transformation from the rhombohedral to monoclinic space groups occurs, as described above, both of which are centrosymmetric. However, the general trends in bandgap size and photocatalytic activity do not show any discontinuities, but rather, both gradually shift and result in lower band energies and higher photocatalytic activities with increasing $\mathrm{Nb}$ content [125]. This suggests the higher activities are the result of increased light absorption, and are not significantly impacted by this specific structural transformation. The further substitution of Sn (II) cations into the structure was partially successful, resulting in a Sn (II) content that varied between $\approx 11 \%$ to $\approx 21 \%$. Significant red-shifting of the bandgap size occurred down to $\approx 2.3 \mathrm{eV}$ into the visible light energies, as well as higher photocatalytic activities for hydrogen formation of up to $\approx 124 \mu \mathrm{mol} \mathrm{H} \mathrm{H}_{2} \cdot \mathrm{h}^{-1} \cdot \mathrm{g}^{-1}$ under ultraviolet and visible-light energies, as shown in Figure 12 [125]. Further, the conduction and valence band energies were both found to maintain suitable positions for driving both the reduction and oxidation of water. However, further research is necessary to elucidate any structural changes and the crystallographic location of the $\mathrm{Sn}(\mathrm{II})$ cations, as well as the preparation of a fully $\mathrm{Sn}$ (II) exchanged composition (i.e., $\mathrm{SnTa}_{4} \mathrm{O}_{11}$ in analogy with $\mathrm{PbTa}_{4} \mathrm{O}_{11}$ ).
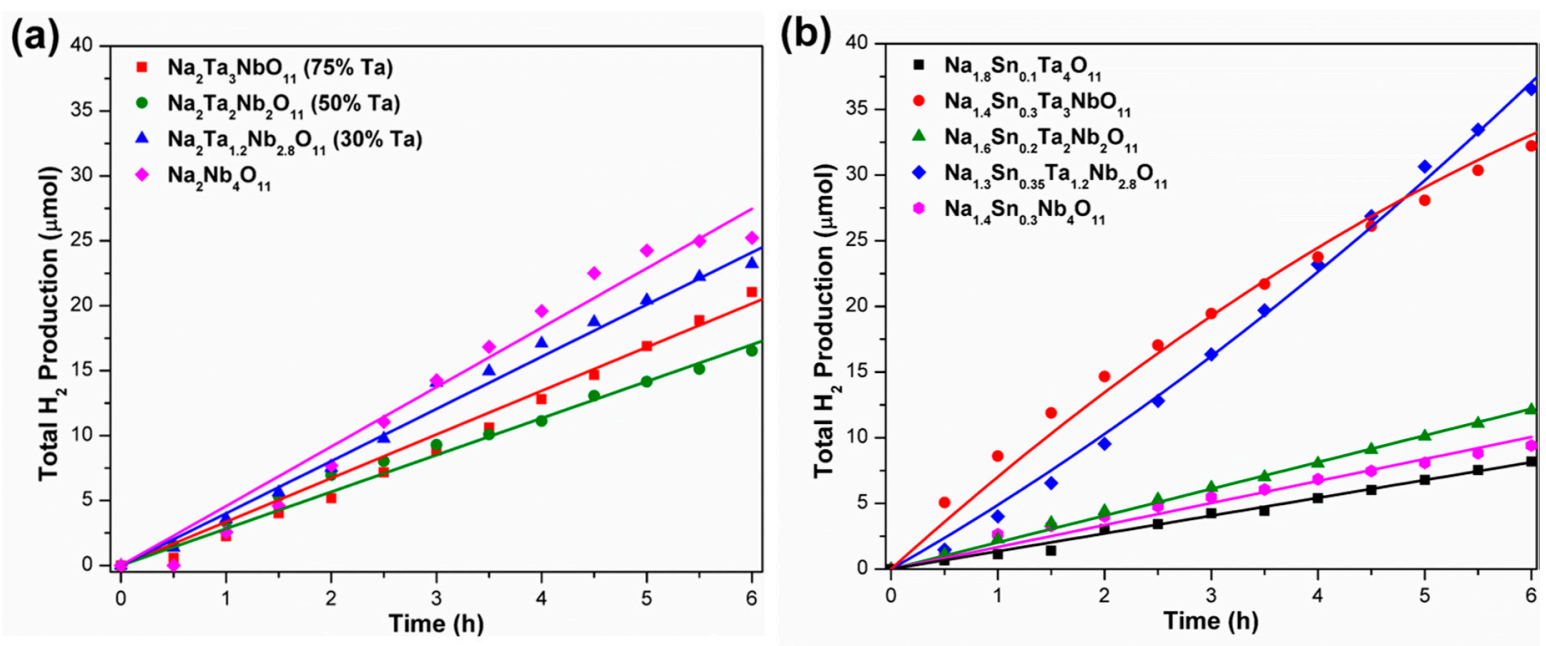

Figure 12. Photocatalytic hydrogen production $\left(\mu \mathrm{mol} \mathrm{H}\right.$ ) versus time (h) for (a) $\mathrm{Na}_{2} \mathrm{Ta}_{4-y} \mathrm{Nb}_{y} \mathrm{O}_{11}$ and (b) $\mathrm{Na}_{2-2 x} \mathrm{Sn}_{x} \mathrm{Ta}_{4-y} \mathrm{Nb}_{y} \mathrm{O}_{11}$ under ultraviolet-visible $(\lambda>230 \mathrm{~nm})$ irradiation. Reprinted with permission from [125]. Copyright 2016 American Chemical Society.

Among the divalent cations of this family, $\mathrm{CaTa}_{4} \mathrm{O}_{11}$ and the related solid solution $\mathrm{Ca}_{1-x} \mathrm{Sr}_{x} \mathrm{Ta}_{4} \mathrm{O}_{11}$, $0 \leq x \leq 0.3$, has been investigated for suspended particle photocatalysis [130]. The bandgap size across this series ranged from $\approx 4.4 \mathrm{eV}$ to $\approx 4.2 \mathrm{eV}$ with increasing Sr content, photocatalytic activities were limited to ultraviolet irradiation. The rate of hydrogen production varied, from $\approx 502 \mu \mathrm{mol} / \mathrm{h}$ with a $\mathrm{NiO}$ cocatalysts to $\approx 20-30 \mu \mathrm{mol} / \mathrm{h}$ without a cocatalyst [130]. Photocatalytic activity was dependent upon the preparation of the sample, co-catalyst, and loading methods of the cocatalyst. Generally, no apparent trends were observed in the rates for increasing amounts of Sr substitution into the compound [130]. The samples were prepared using either a polymerized complex method or impregnation method [130]. For pure $\mathrm{CaTa}_{4} \mathrm{O}_{11}$, rates for hydrogen production were found to be $\approx 403 \mu \mathrm{mol} / \mathrm{h}$ of $\mathrm{H}_{2}$ when loaded with $0.5 \mathrm{wt} \%$ of $\mathrm{NiO}$ co-catalyst in comparison to a rate $\approx 62 \mu \mathrm{mol} / \mathrm{h}$ of $\mathrm{H}_{2}$ when $\mathrm{RuO}_{2}$ was used as the co-catalyst. The solid solution with the highest activity also had the highest $\mathrm{Sr}$ content, (i.e., $\mathrm{Ca}_{0.7} \mathrm{Sr}_{0.3} \mathrm{Ta}_{4} \mathrm{O}_{11}$ ) yielded $\approx 575 \mu \mathrm{mol} / \mathrm{h}$ of $\mathrm{H}_{2}$ in the presence of $\mathrm{NiO}$ co-catalysts on the surface of the photocatalyst and $\approx 16 \mu \mathrm{mol} / \mathrm{h} \mathrm{of} \mathrm{H}_{2}$ without the addition of a co-catalyst [130]. The cited reason for the higher activity was the relaxation of the structural distortion when substituting the larger $\mathrm{Sr}$ cation into the structure. The rates for oxygen production followed generally similar trends, which peaked varied between $\approx 11 \mu \mathrm{mol} / \mathrm{h}$ to 
$\approx 300 \mu \mathrm{mol} / \mathrm{h}$. Thus, relatively high rates of both hydrogen and oxygen production are found, and a high quantum yield of $\approx 5.8 \%$ was measured under $254 \mathrm{~nm}$ irradiation for total water splitting for $\mathrm{Ca}_{0.7} \mathrm{Sr}_{0.3} \mathrm{Ta}_{4} \mathrm{O}_{11}$ with $0.5 \mathrm{wt} \%$ of $\mathrm{NiO}$ as a surface co-catalyst.

The photocatalysis of $\mathrm{PbTa}_{4} \mathrm{O}_{11}$ for hydrogen and oxygen production was investigated under ultraviolet-visible light irradiation, shown in Figure 13. The $\mathrm{PbTa}_{4} \mathrm{O}_{11}$ phase was prepared in high purity by $\mathrm{Pb}(\mathrm{II})$ exchange of either $\mathrm{Ag}_{2} \mathrm{Ta}_{4} \mathrm{O}_{11}$ or the $\mathrm{Na}_{2} \mathrm{Ta}_{4} \mathrm{O}_{11}$ compounds and shows a symmetry-lowering to a polar space group $[35,126]$. The $\mathrm{PbTa}_{4} \mathrm{O}_{11}$ phase exhibits a relatively high rate for hydrogen production of $\approx 175 \mu \mathrm{mol} \mathrm{H} \cdot \mathrm{g}^{-1} \cdot \mathrm{h}^{-1}$ when prepared from the $\mathrm{Ag}_{2} \mathrm{Ta}_{4} \mathrm{O}_{11}$ precursor, and a lower rate of $\approx 72 \mu \mathrm{mol} \mathrm{H} \mathrm{H}_{2} \cdot \mathrm{g}^{-1} \cdot \mathrm{h}^{-1}$ when prepared from $\mathrm{Na}_{2} \mathrm{Ta}_{4} \mathrm{O}_{11}$ [126]. These differences were partially attributed to the higher amounts of $\mathrm{Pb}^{2+}$ cations at the surfaces of $\mathrm{PbTa}_{4} \mathrm{O}_{11}$ prepared from $\mathrm{Ag}_{2} \mathrm{Ta}_{4} \mathrm{O}_{11}$. By comparison, both $\mathrm{Na}_{2} \mathrm{Ta}_{4} \mathrm{O}_{11}$ and $\mathrm{Ag}_{2} \mathrm{Ta}_{4} \mathrm{O}_{11}$ gave lower rates of $\approx 10$ to $\approx 35 \mu \mathrm{mol} \mathrm{H} \mathrm{H}_{2} \cdot \mathrm{g}^{-1} \cdot \mathrm{h}^{-1}$ [126]. However, a further comparison of these rates with those for $\mathrm{Ca}_{1-x} \mathrm{Sr}_{\mathrm{x}} \mathrm{Ta}_{4} \mathrm{O}_{11}$ is not possible owing to the different testing conditions and surface co-catalysts. Shown in Figure 13 (left), the photocatalytic rates for $\mathrm{O}_{2}$ production were calculated from the initial rates over $1 \mathrm{~h}$ for the $\mathrm{PbTa}_{4} \mathrm{O}_{11}$ phase and its precursor, $\mathrm{Ag}_{2} \mathrm{Ta}_{4} \mathrm{O}_{11}$. The rates of $\mathrm{O}_{2}$ production decreased over time as $\mathrm{Ag}(\mathrm{s})$ is deposited onto the particles' surfaces owing to its reduction as a sacrificial reagent. The oxygen production of the $\mathrm{PbTa}_{4} \mathrm{O}_{11}$ phase was found to be $\approx 84 \mu \mathrm{mol} \mathrm{O}_{2} \cdot \mathrm{g}^{-1} \cdot \mathrm{h}^{-1}$, while its precursor $\mathrm{Ag}_{2} \mathrm{Ta}_{4} \mathrm{O}_{11}$ exhibited a higher rate of $\approx 165 \mu \mathrm{mol} \mathrm{O}{ }_{2} \cdot \mathrm{g}^{-1} \cdot \mathrm{h}^{-1}[126]$. The $\mathrm{PbTa}_{4} \mathrm{O}_{11}$ phase with a $1 \mathrm{wt} \%$ platinum co-catalyst exhibited an overall water splitting rate, i.e., for both hydrogen and oxygen production, at a rate of $\approx 34 \mu \mathrm{mol} \mathrm{gas} \mathrm{g}^{-1} \cdot \mathrm{h}^{-1}$ in deionized water under ultraviolet-visible irradiation [126]. The bandgap size of $\mathrm{Ag}_{2} \mathrm{Ta}_{4} \mathrm{O}_{11}$ and $\mathrm{PbTa}_{4} \mathrm{O}_{11}$ are relatively the same $(\approx 3.8 \mathrm{eV})$. The symmetry-lowering structural distortions and resulting electronic distortions in the $\mathrm{PbTa}_{4} \mathrm{O}_{11}$ phase are associated with its relatively higher photocatalytic rates for hydrogen generation compared to other undistorted single-layered structures (i.e., $\mathrm{Na}_{2} \mathrm{Ta}_{4} \mathrm{O}_{11}$ and $\mathrm{Ag}_{2} \mathrm{Ta}_{4} \mathrm{O}_{11}$ ). Out-of-center distortions of $\mathrm{d}^{0}$ transition metal cations have been reported to result in the generation of internal electric fields that can aid in electron/hole charge separation in polar noncentrosymmetric metal oxides, similar to that observed in the $\mathrm{PbTa}_{4} \mathrm{O}_{11}$ phase $[61,131,132]$. The improved electron/hole charge separation due to the internal electric fields can aid in mitigating the effects of recombination and back-reaction, and act to increase photocatalytic hydrogen generation [35].
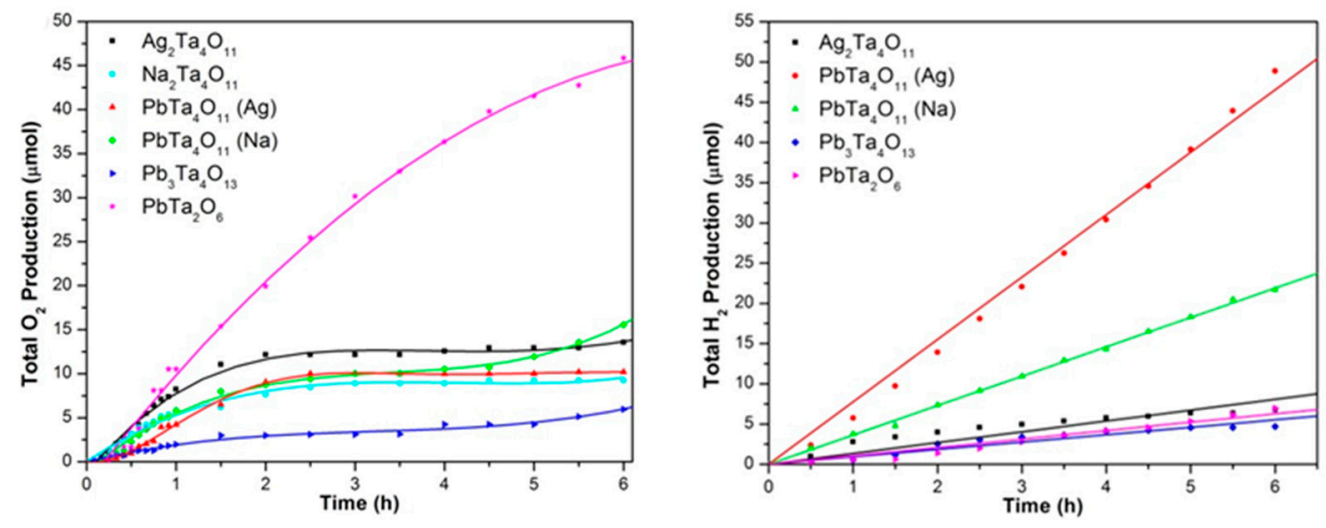

Figure 13. Photocatalytic oxygen production $\left(\mu \mathrm{mol} \mathrm{O}_{2}\right.$; left) and hydrogen ( $\mu \mathrm{mol} \mathrm{H}_{2}$; right) versus time (h) for the $\mathrm{M}_{2} \mathrm{Ta}_{4} \mathrm{O}_{11},(\mathrm{M}=\mathrm{Ag}$, $\mathrm{Ta})$, and $\mathrm{Pb}_{2} \mathrm{Ta}_{4} \mathrm{O}_{11}, \mathrm{~Pb}_{3} \mathrm{Ta}_{4} \mathrm{O}_{13}$, and $\mathrm{PbTa}_{2} \mathrm{O}_{6}$ phases under ultraviolet-visible $(\lambda>230 \mathrm{~nm})$ irradiation. Adapted with permission from [126]. Copyright 2013 American Chemical Society. 


\subsection{Double $\mathrm{MO}_{7}$ Layered Photocatalysts}

The double-layered $\mathrm{BiTa}_{7} \mathrm{O}_{19}$ phase has exhibited hydrogen production under ultraviolet-visible light irradiation in $20 \%$ methanol solution as a suspended particle photocatalyst with a rate of $\approx 194 \mu \mathrm{mol} \mathrm{H} \mathrm{H}_{2} \cdot \mathrm{g}^{-1} \cdot \mathrm{h}^{-1}$. similar to $\mathrm{PbTa}_{4} \mathrm{O}_{11}$ [126]. Analogous to the $\mathrm{PbTa}_{4} \mathrm{O}_{11}$ phase, the photocatalytic rates for $\mathrm{O}_{2}$ production were calculated from the initial $1 \mathrm{~h}$ rate for $\mathrm{BiTa}_{7} \mathrm{O}_{19}$. The $\mathrm{BiTa}_{7} \mathrm{O}_{19}$ phase was found to exhibit a rate of $\approx 140 \mu \mathrm{mol} \mathrm{O}{ }_{2} \cdot \mathrm{g}^{-1} \cdot \mathrm{h}^{-1}$. The $\mathrm{BiTa}_{7} \mathrm{O}_{19}$ phase with a $1 \mathrm{wt} \%$ platinum co-catalyst exhibited total water splitting in deionized water under ultraviolet-visible irradiation with a rate of $\approx 34 \mu \mathrm{mol}$ gas $\mathrm{g}^{-1} \cdot \mathrm{h}^{-1}$ [126]. Anisotropic migration of charge carriers along the $\mathrm{TaO}_{7}$ pentagonal bipyramid double layers in $\mathrm{BiTa}_{7} \mathrm{O}_{19}$ may aid in charge separation and facilitate its higher suspended particle photocatalytic activity. The suspended particle photocatalytic gas generation rates of double layered metal-oxides have been reported to be some of the highest, such as layered perovskites, and may account for its reported higher activity in comparison to the single-layered $\mathrm{A}_{2} \mathrm{Ta}_{4} \mathrm{O}_{11}(\mathrm{~A}=\mathrm{Na}, \mathrm{Ag})$ phases $[24,113,126,133]$.

The suspended particle photocatalytic rates of the related $\mathrm{Cu}(\mathrm{I})$-tantalates and -niobates have not been as intensely investigated currently. In a recent example, $\mathrm{Cu}_{3} \mathrm{Ta}_{7} \mathrm{O}_{19}$ was investigated for suspended particle photocatalysis where $\mathrm{H}_{2}$ was produced at the relatively rate of $0.1 \mu \mathrm{mol} \mathrm{H} \mathrm{H}_{2} \cdot \mathrm{h}^{-1} \cdot \mathrm{g}^{-}$[119]. Rather, these materials have been investigated in the form of polycrystalline films as p-type semiconductors, and which show significant cathodic photocurrents in the range of -0.5 to $-3.0 \mathrm{~mA} / \mathrm{cm}^{2}$, but these efforts have been covered more extensively in a recent review [85].

\section{Conclusions}

The crystallography and photocatalytic properties of a polysomatic family of ternary mixed-metal oxides, $\mathrm{A}^{m+}{ }_{((n+1) / m)} \mathrm{B}_{(3 n+1)} \mathrm{O}_{(8 n+3)}$ (e.g., $\mathrm{A}=\mathrm{Ag}, \mathrm{Bi}, \mathrm{Ca}, \mathrm{Cu}, \mathrm{Ce}, \mathrm{Dy}, \mathrm{Eu}, \mathrm{Gd} \mathrm{K}, \mathrm{La}, \mathrm{Nd}, \mathrm{Pb}, \mathrm{Pr}, \mathrm{Sr}, \mathrm{Y}$; $\mathrm{B}=\mathrm{Nb}, \mathrm{Ta}) ; m=1-3 ; n=1,1.5,2)$, which feature the layers of pentagonal bipyramids contained in the $\alpha-\mathrm{U}_{3} \mathrm{O}_{8}$ structure type (with mixed six- and seven-coordination sites) are reviewed. These compounds highlight either single, double, triple, or mixed layers of edge-sharing $\mathrm{BO}_{7}$ pentagonal bipyramid layers alternating with isolated octahedral layers, as well as A-site cations with 2-, 6-, 7-, or 8 -coordination depending on their oxidation state. Some of the members exhibit symmetry lowering phase transitions as a function of chemical composition, temperature, and reaction conditions. These symmetry lowering structure distortions, and the resulting electronic distortions have important consequences for photocatalytic applications. As illustrated by the $\mathrm{PbTa}_{4} \mathrm{O}_{11}$ phase which shows an out-of-plane distortion of the $\mathrm{d}^{0}$ transition metal cation, an internal electric dipole can facilitate the electron/hole charge separation, thus mitigating the effects of recombination and back-reaction. It was also found that the higher charge of the cation $\mathrm{A}$ (for example in $\mathrm{BiTa}_{7} \mathrm{O}_{19}$ ) can help charge separation due to the anisotropic migration of charge carriers along the $\mathrm{BO}_{7}$ pentagonal bipyramid double layers, giving rise to higher photocatalytic rate for hydrogen generation.

Supplementary Materials: The following are available online at www.mdpi.com/2073-4352/7/5/145/s1, Table S1: Selected members comprised with single pentagonal bipyramid layers alternating with octahedral layers, Table S2: General trends for extended structure comprised with single pentagonal bipyramid layers, Table S3: Selected members comprised with single and double pentagonal bipyramid layers alternating with octahedral layers, Table S4: Selected members comprised with double pentagonal bipyramid layers alternating with octahedral layers, Table S5: selected members comprised with single and triple pentagonal bipyramid layers alternating with octahedral layers.

Acknowledgments: The authors would like to thank the National Research Council Research Associateship Program and the National Institute of Standards and Technology. This is a feature article and the publication fee has been waived.

Author Contributions: Nacole King and Jonathan Boltersdorf conceived the concept for the feature article; Nacole King wrote the manuscript, prepared figures, analyzed data: Jonathan Boltersdorf, Paul A. Maggard, Winnie Wong-Ng co-wrote and revised the manuscript.

Conflicts of Interest: The authors declare no conflict of interest. 


\section{References}

1. Zhu, J.; Li, H.; Zhong, L.; Xiao, P.; Xu, X.; Yang, X.; Zhao, Z.; Li, J. Perovskite oxides: Preparation, Characterizations, and Applications in Heterogeneous Catalysis. ACS Catal. 2014, 4, 2917-2940. [CrossRef]

2. Zeng, Z.; Calle-Vallejo, F.; Mogensen, M.B.; Rossmeisl, J. Generalized trends in the formation energies of perovskite oxides. Phys. Chem. Chem. Phys. 2013, 15, 7526-7533. [CrossRef] [PubMed]

3. Huang, K.; Yuan, L.; Feng, S. Crystal Facet Tailoring Art in Perovskite Oxides. Inorg. Chem. Front. 2015, 2, 965-981. [CrossRef]

4. Bhalla, A.S.; Guo, R.; Roy, R. The perovskite structure-A review of its role in ceramic science and technology. Mater. Res. Innov. 2000, 4, 3-26. [CrossRef]

5. Pena, M.A.; Fierro, J.L.G. Chemical Structures and Performance of Perovskite Oxides. Chem. Rev. 2001, 101, 1981-2017. [CrossRef] [PubMed]

6. Balachandran, P.V.; Puggioni, D.; Rondinelli, J.M. Crystal-Chemistry Guidelines for Noncentrosymmetric A2BO4 Ruddlesden-Popper Oxides. Inorg. Chem. 2014, 53, 336-348. [CrossRef] [PubMed]

7. Bhuvanesh, N.S.P.; Crossnier-Lopez, M.P.; Duroy, H.; Fourquet, J.L. Synthesis and Structure of Novel Layered perovskite oxides. J. Chem. Soc. 1999, 9, 3093-3100. [CrossRef]

8. Crosnier-Lopez, M.-P.; Le Berre, F.; Fourquet, J.L. The layered perovskite $\mathrm{K}_{2} \mathrm{SrTa}_{2} \mathrm{O}_{7}$ : Hydration and $\mathrm{K}+/ \mathrm{H}+$ Ion exchange. J. Mater. Chem. 2001, 11, 1146-1151. [CrossRef]

9. Zhang, P.; Li, X.; Zhao, Q.; Liu, S. Synthesis and optical property of one-dimensional spinel $\mathrm{ZnMn}_{2} \mathrm{O} 4$ nanorods. Nanoscale Res. Lett. 2011, 6, 323. [CrossRef] [PubMed]

10. Zerarga, F.; Bouhemadou, A.; Khenata, R.; Bin-Omran, S. Structural, electronic and optical properties of spinel oxides $\mathrm{ZnAl}_{2} \mathrm{O}_{4}, \mathrm{ZnGa}_{2} \mathrm{O}_{4}$ and $\mathrm{ZnIn}_{2} \mathrm{O}_{4}$. Solid State Sci. 2011, 13, 1638-1648. [CrossRef]

11. O'Neill, H.S.C.; Navrotsky, A. Simple spinels: Crystallographic parameters, cation radii, lattice energies, and cation distribution. Am. Mineral. 1983, 68, 181-194.

12. Vivanco, H.K.; Rodriguez, E.E. The intercalation chemistry of layered iron chalcogenide superconductors. J. Solid State Chem. 2016, 242, 3-21. [CrossRef]

13. Pickett, W.E. Electronic structure of the high-temperature oxide superconductors. Rev. Mod. Phys. 1989, 61, 433-512. [CrossRef]

14. Ren, Z.A.; Zhao, Z.X. Research and prospects of iron-based superconductors. Adv. Mater. 2009, 21, 4584-4592. [CrossRef]

15. Cava, R.J. Oxide Superconductors. J. Am. Ceram. Soc. 2000, 83, 5-28. [CrossRef]

16. Zhang, K.H.L.; Xi, K.; Blamire, M.G.; Egdell, R.G. p-Type transparent conducting oxides. J. Phys. Condens. Matter 2016, 28, 383002. [CrossRef] [PubMed]

17. Exarhos, G.J.; Zhou, X.-D. Discovery-based design of transparent conducting oxide films. Thin Solid Films 2007, 515, 7025-7052. [CrossRef]

18. Hosono, H. Recent progress in transparent oxide semiconductors: Materials and device application. Thin Solid Films 2007, 515, 6000-6014. [CrossRef]

19. Hoel, C.A.; Mason, T.O.; Gaillard, J.F.; Poeppelmeier, K.R. Transparent Conducting Oxides in the $\mathrm{ZnO}-\mathrm{In}_{2} \mathrm{O}_{3}-\mathrm{SnO}_{2}$ System. Chem. Mater. 2010, 22, 3569-3579. [CrossRef]

20. Dixon, S.C.; Scanlon, D.O.; Carmalt, C.J.; Parkin, I.P. n-Type doped transparent conducting binary oxides: An overview. J. Mater. Chem. 2016, 419, 462-465. [CrossRef]

21. Maeda, K. Photocatalytic water splitting using semiconductor particles: History and recent developments. J. Photochem. Photobiol. C Photochem. Rev. 2011, 12, 237-268. [CrossRef]

22. Abe, R. Recent progress on photocatalytic and photoelectrochemical water splitting under visible light irradiation. J. Photochem. Photobiol. C Photochem. Rev. 2010, 11, 179-209. [CrossRef]

23. Kudo, A. Development of photocatalyst materials for water splitting. Int. J. Hydrogen Energy 2006, 31, 197-202. [CrossRef]

24. Osterloh, F.E. Inorganic nanostructures for photoelectrochemical and photocatalytic water splitting. Chem. Soc. Rev. 2013, 42, 2294-2320. [CrossRef] [PubMed]

25. Martsinovich, N. Theory of materials for solar energy conversion. J. Phys. Condens. Matter 2016, $28,70301$. [CrossRef] [PubMed]

26. Shi, J.; Guo, L. ABO3-based photocatalysts for water splitting. Prog. Nat. Sci. Mater. Int. 2012, $22,592-615$. [CrossRef] 
27. Zachariasen, W.H. Crystal chemical studies of the $5 \mathrm{f}$-series of elements. XII. New compounds representing known structure types. Acta Crystallogr. 1949, 2, 388-390. [CrossRef]

28. Chodura, B.; Maly, J. A Contribution to the solution of the Structure of U3O8. J. Inorg. Nucl. Chem. 1958, 7, 177-178.

29. Andresen, A.F. The Structure of U3O8 Determined by Neutron Diffraction. Acta Crystallogr. 1958, 11, 612-614. [CrossRef]

30. Loopstra, B.O. Neutron Diffraction Investigation of U3O8. Acta Crystallogr. 1964, 17, 651-654. [CrossRef]

31. Loopstra, B.O. The structure of $\beta-\mathrm{U}_{3} \mathrm{O}_{8}$. Acta Crystallogr. Sect. B Struct. Crystallogr. Cryst. Chem. 1970, 26, 656-657. [CrossRef]

32. Momin, A.C.; Deshapande, V.V.; Karkhanavala, M.D. Phase Transition Studies of $\mathrm{U}_{3} \mathrm{O}_{8}$. J. Nucl. Mater. 1973, 48, 360-364. [CrossRef]

33. Loopstra, B.O. On The Existence of delta U3O8: A comment on papers by Karkhanavalla. J. Nucl. Mater. 1969, 29, 354-355. [CrossRef]

34. Loopstra, B.O. The Phase Transition in alpha $\mathrm{U}_{3} \mathrm{O}_{8}$ at 210. J. Appl. Cryst. 1970, 3, 94-96. [CrossRef]

35. Boltersdorf, J.; Maggard, P.A. Structural and electronic investigations of $\mathrm{PbTa}_{4} \mathrm{O}_{11}$ and $\mathrm{BiTa}_{7} \mathrm{O}_{19}$ constructed from $\alpha$-U3O8 types of layers. J. Solid State Chem. 2015, 229, 310-321. [CrossRef]

36. Jahnberg, L. Hexa- and Hepta-Coordination in Niobium and Tantalum Oxides and Oxide Flourides and Structurally Related Compounds.pdf. Chem. Comm. 1971, 1-41.

37. Jahnberg, L. A series of Strucutres based on the stacking of alpha U3O8 Layers of pentagonal bipyramids. Mat. Res. Bull. 1981, 16, 513-518. [CrossRef]

38. Jahnberg, L. Crystal structures of $\mathrm{Na}_{2} \mathrm{Nb}_{4} \mathrm{O}_{11}$ and $\mathrm{CaTa}_{4} \mathrm{O}_{11}$. J. Solid State Chem. 1970, 3-4, 454-462. [CrossRef]

39. HeuNen, G.W.J.C.; IJdo, D.J.W. SrTa $\mathrm{O}_{11}$ : A Rietveld Refinement using Neutron Powder Diffraction Data. Acta Cryst. 1995, C51, 1723-1725. [CrossRef]

40. Jahnberg, L.; Sundberg, M. HREM studies of phases based on alpha- $\mathrm{U}_{3} \mathrm{O}_{8}$-type layers in the $\mathrm{Cu}_{2} \mathrm{O}_{-} \mathrm{Ta}_{2} \mathrm{O}_{5}$ system. J. Solid State Chem. 1992, 100, 212-219. [CrossRef]

41. Babaryk, A.A.; Odynets, I.V.; Khainakov, S.; Slobodyanik, N.S.; Garcia-Granda, S. $\mathrm{K}_{2} \mathrm{Ta}_{4} \mathrm{O}_{11}$ ("kalitantite”): A wide band gap semiconductor synthesized in molybdate flux medium. CrystEngComm 2013, 15, 5539-5544. [CrossRef]

42. Masó, N.; Woodward, D.I.; Várez, A.; West, A.R. Polymorphism, structural characterisation and electrical properties of $\mathrm{Na}_{2} \mathrm{Nb}_{4} \mathrm{O}_{11}$. J. Mater. Chem. 2011, 21, 12096-12102. [CrossRef]

43. Masó, N.; Woodward, D.I.; Thomas, P.A.; Várez, A.; West, A.R. Structural characterization of ferroelectric $\mathrm{Ag}_{2} \mathrm{Nb}_{4} \mathrm{O}_{11}$ and dielectric $\mathrm{Ag}_{2} \mathrm{Ta}_{4} \mathrm{O}_{11}$. J. Mater. Chem. 2011, 21, 2715-2722. [CrossRef]

44. Jahnberg, L. Structure of the Copper (I) Tantalum Oxide, $\mathrm{Cu}_{5} \mathrm{Ta}_{11} \mathrm{O}_{30}$. J. Solid State Chem. 1982, 41, $286-292$. [CrossRef]

45. Kwentus, Y.; Willson, N. Synthesis and Crystal Strucutre of $\mathrm{Th}_{2} \mathrm{Th}_{6} \mathrm{O}_{19}$, the first example of a Jahnberg-Structure. Z. Anorg. Allg. Chem. 1996, 622, 67-75. [CrossRef]

46. Stemmer, W.; Gruehn, R. Tantalated and Niobate Metlts. Z. Anorg. Allg. Chem. 1993, 619, 409-415. [CrossRef]

47. Palasyuk, O.; Palasyuk, A.; Maggard, P.A. Syntheses, optical properties and electronic structures of copper(I) tantalates: $\mathrm{Cu}_{5} \mathrm{Ta}_{11} \mathrm{O}_{30}$ and $\mathrm{Cu}_{3} \mathrm{Ta}_{7} \mathrm{O}_{19}$. J. Solid State Chem. 2010, 183, 814-822. [CrossRef]

48. Jahnberg, L. Phase Analysis Studies in the System $\mathrm{Cu}_{2} \mathrm{O}-\mathrm{Ta}_{2} \mathrm{O}_{5}$. Acta Chem. Scand. 1987, 41, $527-532$. [CrossRef]

49. Eibenstein, U.; Jung, W. A New Praseodymiumniobate $\operatorname{Pr}_{2} \mathrm{Nb}_{11} \mathrm{O}_{30}$. Z. Anorg. Allg. Chem. 1998, 624, 802-806. [CrossRef]

50. Gatehouse, B.M. Crystal Structures Part V: $\mathrm{CeTa}_{7} \mathrm{O}_{19}$ of Some Niobium and Tantalum. J. Solid State Chem. 1979, 27, 209-213. [CrossRef]

51. Guo, G.C.; Zhuang, J.N.; Wang, Y.G.; Chen, J.T.; Zhuang, H.H.; Huang, J.S.; Zhang, Q.E. Dysprosium Tantalum Oxide, DyTa $\mathrm{O}_{19}$. Acta Crystallogr. Sect. C Cryst. Struct. Commun. 1996, 52, 5-7. [CrossRef]

52. Langebach-Kuttert, B.; Sturm, J.; Gruehn, R. On the Structure of $\mathrm{LaTa}_{7} \mathrm{O}_{19}$ Xray and Electron Microscopy. Z. Anorg. Allg. Chem. 1986, 543, 117-128.

53. Rossell, H.J.; Scott, H.G. The unit cell of YTa7O19, A new compound, and its isomorphism with the corresponding rare earth tantalates. Mater. Res. Bull. 1976, 11, 1231-1235. [CrossRef]

54. Cretien, A.; Bodit, D. Synthesis of Rare Earth Niobates. C. R. Acad. Sci. Paris 1966, 263C, 882. 
55. Kubota, S.; Endo, T. Energy migration in $\mathrm{EuTa}_{7} \mathrm{O}_{19}, \mathrm{TbTa}_{7} \mathrm{O}_{19}$ and $\mathrm{La}_{0.86} \mathrm{Tm}_{\mathrm{o} .14} \mathrm{Ta}_{7} \mathrm{O}_{19}$. J. Alloys Compd. 1996, 241, 16-21. [CrossRef]

56. Johnson, A.W.S.; Gatehouse, B.M. Convergent-Beam Electron Diffraction Symmetry from a Disordered Structure (Ce,Ta)Ta ${ }_{6} \mathrm{O}_{19}$. Acta Crystallogr. Sect. B Struct. Crystallogr. Cryst. Chem. 1980, 36, 523-526. [CrossRef]

57. Hofmann, R.; Gruehn, R. Zur Darstellung und Struktur neuer Niobate $\mathrm{LnNb}_{7} \mathrm{O}_{19}$ (Ln = La, Ce). Z. Anorg. Allg. Chem. 1991, 602, 105-117. [CrossRef]

58. Hofmann, R. Synthesis of Rare Earth Solid State Compounds by Using Chemical Transport. Ph.D. Thesis, University Giessen, Gießen, Germany, 1993.

59. Halasyamani, P.S.; Poeppelmeier, K.R. Noncentrosymmetric Oxides. Chem. Mater. 1998, 10, $2753-2769$. [CrossRef]

60. Woodward, P.M.; Mizoguchi, H.; Kim, Y.I.; Stoltzfus, M.W. Metal Oxides: Chemistry and Applications; CRC Press: Boca Raton, FL, USA, 2005; Volume 108, pp. 133-194. [CrossRef]

61. Kunz, M.; Brown, I.D. Out-of-Center Distortions around Octahedrally Coordinated d0 Transition Metals. J. Solid State Chem. 1995, 115, 395-406. [CrossRef]

62. Masó, N.; West, A.R. A new family of ferroelectric materials: $\mathrm{Me}_{2} \mathrm{Nb}_{4} \mathrm{O}_{11}(\mathrm{Me}=\mathrm{Na}$ and Ag). J. Mater. Chem. 2010, 20, 2082-2084. [CrossRef]

63. Ercit, T.S.; Hawthorne, C.; Cerny, P. Crystal Structure of synthetic natrotantite. Bull. Miner. 1985, 108, $541-549$.

64. King, N.; Sullivan, I.; Watkins-Curry, P.; Chan, J.Y.; Maggard, P.A. Flux-mediated syntheses, structural characterization and low-temperature polymorphism of the p-type semiconductor $\mathrm{Cu}_{2} \mathrm{Ta}_{4} \mathrm{O}_{11}$. J. Solid State Chem. 2016, 236, 10-18. [CrossRef]

65. King, N.; Sommer, R.D.; Watkins-Curry, P.; Chan, J.Y.; Maggard, P.A. Synthesis, Structure, and Thermal Instability of the $\mathrm{Cu}_{2} \mathrm{Ta}_{4} \mathrm{O}_{11}$ Phase. Cryst. Growth Des. 2015, 15, 552-558. [CrossRef]

66. Goodenough, J.B.; Longo, J.M. ABX Perowskit-Struktur. In Magnetic and Other Properties of Oxides and Related Compounds; Springer-Verlag: Berlin/Heidelberg, Germany, 1970; pp. 142-144. ISBN: 978-3-540-04898-5.

67. Kang, S.K.; Tang, H.; Albright, T.A. Structures for d0 ML6 and ML5 complexes. J. Am. Chem. Soc. 1993, 115, 1971-1981. [CrossRef]

68. Wheeler, R.A.; Whangbo, M.H.; Hughbanks, T.; Hoffman, R. Symmetric vs. Asymmetric Linear M-X-M Linkages in Molecules, Polymers, and Extended Networks. J. Am. Chem. Soc. 1986, 108, 2222-2236. [CrossRef] [PubMed]

69. Woodward, D.I.; Lees, M.R.; Thomas, P.A. Structural phase transitions in the $\mathrm{Ag}_{2} \mathrm{Nb}_{4} \mathrm{O}_{11}-\mathrm{Na}_{2} \mathrm{Nb}_{4} \mathrm{O}_{11}$ solid solution. J. Solid State Chem. 2012, 192, 385-389. [CrossRef]

70. Masó, N.; West, A.R. Dielectric properties, polymorphism, structural characterisation and phase diagram of Na2Nb4O11-Ag2Nb4O11 solid solutions. J. Solid State Chem. 2015, 225, 438-449. [CrossRef]

71. Palasyuk, O.; Palasyuk, A.; Maggard, P.A. Site-Differentiated Solid Solution in $\mathrm{Na}_{1-} \mathrm{Cu}_{\mathrm{x}} \mathrm{Ta}_{4} \mathrm{O}_{11}$ and Its Electronic Structure and Optical Properties. Inorg. Chem. 2010, 49, 10571-10578. [CrossRef] [PubMed]

72. Nocera, D.G.; Lewis, S.N. Powering the Planet: Chemical challages in solar energy utillization. PNAS 2006, 103, 15729-15735. [CrossRef]

73. Yuan, L.; Han, C.; Yang, M.-Q.; Xu, Y.-J. Photocatalytic water splitting for solar hydrogen generation: Fundamentals and recent advancements. Int. Rev. Phys. Chem. 2016, 35, 1-36. [CrossRef]

74. Walter, M.G.; Warren, E.L.; McKone, J.R.; Boettcher, S.W.; Mi, Q.; Santori, E.A.; Lewis, N.S. Solar Water Splitting Cells. Chem. Rev. 2010, 110, 6446-6473. [CrossRef] [PubMed]

75. Pan, H. Principles on design and fabrication of nanomaterials as photocatalysts for water-splitting. Renew. Sustain. Energy Rev. 2016, 57, 584-601. [CrossRef]

76. Fujishima, A.; Honda, K. Electrochemical photolysis of water at a semiconductor electrode. Nature 1972, 238, 37-38. [CrossRef] [PubMed]

77. Chen, J.; Yang, D.; Song, D.; Jiang, J.; Ma, A.; Hu, M.Z.; Ni, C. Recent progress in enhancing solar-to-hydrogen efficiency. J. Power Sources 2015, 280, 649-666. [CrossRef]

78. Rimoldi, L.; Meroni, D.; Falletta, E.; Ferretti, A.M.; Gervasini, A.; Cappelletti, G.; Ardizzone, S. The role played by different $\mathrm{TiO}_{2}$ features on the photocatalytic degradation of paracetamol. Appl. Surf. Sci. 2017. [CrossRef]

79. Chen, C.; Ma, W.; Zhao, J. Semiconductor-mediated photodegradation of pollutants under visible-light irradiation. Chem. Soc. Rev. 2010, 39, 4206-4219. [CrossRef] [PubMed] 
80. Zhang, A.Y.; Long, L.L.; Liu, C.; Li, W.W.; Yu, H.Q. Chemical recycling of the waste anodic electrolyte from the $\mathrm{TiO}_{2}$ nanotube preparation process to synthesize facet-controlled $\mathrm{TiO} 2$ single crystals as an efficient photocatalyst. Green Chem. 2014, 16, 2745-2753. [CrossRef]

81. Rajamanickam, D.; Shanthi, M. Photocatalytic degradation of an organic pollutant by zinc oxide-Solar process. Arab. J. Chem. 2012, 9, S1858-S1868. [CrossRef]

82. Bowker, M. Sustainable hydrogen production by the application of ambient temperature photocatalysis. Green Chem. 2011, 13, 2235-2246. [CrossRef]

83. Serpone, N.; Sauvé, G.; Koch, R.; Tahiri, H.; Pichat, P.; Piccinini, P.; Pelizzetti, E.; Hidaka, H. Standardization protocol of process efficiencies and activation parameters in heterogeneous photocatalysis: Relative photonic efficiencies Zr. J. Photochem. Photobiol. A Chem. 1996, 94, 191-203. [CrossRef]

84. Shi, X.; Cai, L.; Ma, M.; Zheng, X.; Park, J.H. General Characterization Methods for Photoelectrochemical Cells for Solar Water Splitting. ChemSusChem 2015, 8, 3192-3203. [CrossRef] [PubMed]

85. Bard, A.J. Photelectrochemistry and Heterogeneous Photocatalysis At Semiconductors. J. Photochem. 1979, 10, 59-75. [CrossRef]

86. Ismail, A.A.; Bahnemann, D.W. Photochemical splitting of water for hydrogen production by photocatalysis: A review. Sol. Energy Mater. Sol. Cells 2014, 128, 85-101. [CrossRef]

87. Chen, X.; Shen, S.; Guo, L.; Mao, S.S. Semiconductor-based Photocatalytic Hydrogen Generation. Chem. Rev. 2010, 110, 6503-6570. [CrossRef] [PubMed]

88. Liu, G.; Niu, P.; Cheng, H.M. Visible-light-active elemental photocatalysts. ChemPhysChem 2013, 14, 885-892. [CrossRef] [PubMed]

89. Li, Y.; Zhang, J.Z. Hydrogen generation from photoelectrochemical water splitting based on nanomaterials. Laser Photonics Rev. 2010, 4, 517-528. [CrossRef]

90. Bae, D.; Seger, B.; Vesborg, P.C.K.; Hansen, O.; Chorkendorff, I. Strategies for stable water splitting via protected photoelectrodes. Chem. Soc. Rev. 2017, 46, 1933-1954. [CrossRef] [PubMed]

91. Yang, J.; Yan, H.; Zong, X.; Wen, F.; Liu, M.; Li, C. Roles of cocatalysts in semiconductor-based photocatalytic hydrogen production. Philos. Trans. R. Soc. London A Math. Phys. Eng. Sci. 2013, 371, 20110430. [CrossRef] [PubMed]

92. Sullivan, I.; Zoellner, B.; Maggard, P.A. Copper(I)-Based p -Type Oxides for Photoelectrochemical and Photovoltaic Solar Energy Conversion. Chem. Mater. 2016, 28, 5999-6016. [CrossRef]

93. Chen, Z.; Huyen, D.; Miller, E. Photoelectrochemical Water Splitting Standards, Experimental Methods, and Protocols; Springer: New York, NY, USA, 2013; ISBN: 9781461482970.

94. Li, Z.; Luo, W.; Zhang, M.; Feng, J.; Zou, Z. Photoelectrochemical cells for solar hydrogen production: Current State of promissing photoelectrodes, methods to improve their properties, and outlook. Energy Environ. Sci. 2013, 6, 347-370. [CrossRef]

95. Zhang, Z.; Yates, J.T. Band bending in semiconductors: Chemical and physical consequences at surfaces and interfaces. Chem. Rev. 2012, 112, 5520-5551. [CrossRef] [PubMed]

96. Rimoldi, L.; Ambrosi, C.; Di Liberto, G.; Lo Presti, L.; Ceotto, M.; Oliva, C.; Meroni, D.; Cappelli, S.; Cappelletti, G.; Soliveri, G. Impregnation versus Bulk Synthesis: How the Synthetic Route Affects the Photocatalytic Efficiency of Nb/Ta:N Codoped TiO2 Nanomaterials. J. Phys. Chem. 2015, 119, 24104-24115. [CrossRef]

97. Meng, X.; Zhang, Z. Bismuth-Based Photocatalytic Semiconductors: Introduc-tion, Challenges and Possible Approaches. J. Mol. Catal. A Chem. 2016, 423, 533-549. [CrossRef]

98. Zhang, Y.; Ji, H.; Ma, W.; Chen, C.; Song, W.; Zhao, J. Doping-promoted solar water oxidation on hematite photoanodes. Molecules 2016, 21, 1-15. [CrossRef] [PubMed]

99. Minggu, L.J.; Wan Daud, W.R.; Kassim, M.B. An overview of photocells and photoreactors for photoelectrochemical water splitting. Int. J. Hydrogen Energy 2010, 35, 5233-5244. [CrossRef]

100. Nowotny, J.; Sorrell, C.C.; Sheppard, L.R.; Bak, T. Solar-hydrogen: Environmentally safe fuel for the future. Int. J. Hydrogen Energy 2005, 30, 521-544. [CrossRef]

101. Sivula, K.; Van de Krol, R. Semiconducting materials for photoelectrochemical energy conversion. Nat. Rev. Mater. 2016, 1, 15010. [CrossRef]

102. Gratzel, M. Photoelectrochemical Cells. Nature 2001, 414, 338-344. [CrossRef] [PubMed]

103. Kudo, A.; Miseki, Y. Heterogeneous photocatalyst materials for water splitting. Chem. Soc. Rev. 2009, 38, 253-278. [CrossRef] [PubMed] 
104. Luo, B.; Liu, G.; Wang, L. Recent advances in 2D materials for photocatalysis. Nanoscale 2016, 8, 6904-6920. [CrossRef] [PubMed]

105. Satsangi, V.R. Metal Oxide Semiconductors in PEC Splitting of Water. Sol. Hydrog. Nanotechnol. 2007, 6650, 66500D-66500D-13. [CrossRef]

106. Xu, D.; Hai, Y.; Zhang, X.; Zhang, S.; He, R. $\mathrm{Bi}_{2} \mathrm{O}_{3}$ cocatalyst improving photocatalytic hydrogen evolution performance of $\mathrm{TiO}_{2}$. Appl. Surf. Sci. 2017, 400, 530-536. [CrossRef]

107. Paracchino, A.; Laporte, V.; Sivula, K.; Grätzel, M.; Thimsen, E. Highly active oxide photocathode for photoelectrochemical water reduction. Nat. Mater. 2011, 10, 456-461. [CrossRef] [PubMed]

108. Tang, H.; Zhang, D.; Tang, G.; Ji, X.; Li, W.; Li, C.; Yang, X. Hydrothermal synthesis and visible-light photocatalytic activity of $\alpha-\mathrm{Fe} 2 \mathrm{O} 3 / \mathrm{TiO} 2$ composite hollow microspheres. Ceram. Int. 2013, 39, 8633-8640. [CrossRef]

109. Yourey, J.E.J.; Pyper, K.J.K.; Kurtz, J.B.; Bartlett, B.M. Chemical Stability of $\mathrm{CuWO}_{4}$ for Photoelectrochemical Water Oxidation. J. Phys. Chem. 2013, 117, 8708-8718. [CrossRef]

110. Horie, H.; Iwase, A.; Kudo, A. Photocatalytic Properties of Layered Metal Oxides Substituted with Silver by a Molten $\mathrm{AgNO}_{3}$ Treatment. ACS Appl. Mater. Interfaces 2015, 14638-14643. [CrossRef] [PubMed]

111. Abdi, F.F.; Firet, N.; Van de Krol, R. Efficient $\mathrm{BiVO}_{4}$ Thin Film Photoanodes Modified with Cobalt Phosphate Catalyst and W-doping. ChemCatChem 2013, 5, 490-496. [CrossRef]

112. Gu, J.; Wuttig, A.; Krizan, J.W.; Hu, Y.; Detweiler, Z.M.; Cava, R.J.; Bocarsly, A.B. Mg-Doped CuFeO 2 photocathodes for photoelectrochemical reduction of carbon dioxide. J. Phys. Chem. 2013, 117, 12415-12422. [CrossRef]

113. Arney, D.; Maggard, P.A. Effect of Platelet-Shaped Surfaces and Silver-Cation Exchange on the Photocatalytic Hydrogen Production of $\mathrm{RbLaNb}_{2} \mathrm{O}_{7}$. J. Phys. Chem. 2012, 116, 14022-14030. [CrossRef]

114. Hu, Y.; Guo, L. Rapid preparation of perovskite lead niobate nanosheets by ultrasonic-assisted exfoliation for enhanced visible-light-driven photocatalytic hydrogen production. ChemCatChem 2015, 7, 584-587. [CrossRef]

115. Kanhere, P.; Chen, Z. A review on visible light active perovskite-based photocatalysts. Molecules 2014, 19, 19995-20022. [CrossRef] [PubMed]

116. Joshi, U.A.; Palasyuk, A.; Arney, D.; Maggard, P.A. Semiconducting oxides to facilitate the conversion of solar energy to chemical fuels. J. Phys. Chem. Lett. 2010, 1, 2719-2726. [CrossRef]

117. Kudo, A. Photocatalytic decomposition of water over $\mathrm{NiO}-\mathrm{Kb}_{4} \mathrm{Nb}_{6} \mathrm{O}_{17}$ catalyst. J. Catal. 1988, 111, 67-76. [CrossRef]

118. Machida, M.; Mitsuyama, T.; Ikeue, K. Photocatalytic Property and Electronic Structure of Triple-Layered Perovskite Tantalates. J. Phys. Chem. 2005, 109, 7801-7806. [CrossRef] [PubMed]

119. Kulischow, N.; Ladasiu, C.; Marschall, R. Layered Dion-Jacobson type niobium oxides for photocatalytic hydrogen production prepared via molten salt synthesis. Catal. Today 2016, 287, 65-69. [CrossRef]

120. Arney, D.; Porter, B.; Greve, B.; Maggard, P.A. New molten-salt synthesis and photocatalytic properties of $\mathrm{La}_{2} \mathrm{Ti}_{2} \mathrm{O}_{7}$ particles. J. Photochem. Photobiol. A Chem. 2008, 199, 230-235. [CrossRef]

121. Arney, D.; Fuoco, L.; Boltersdorf, J.; Maggard, P.A. Flux Synthesis of $\mathrm{Na}_{2} \mathrm{Ca}_{2} \mathrm{Nb}_{4} \mathrm{O}_{13}$ : The Influence of Particle Shapes, Surface Features, and Surface Areas on Photocatalytic Hydrogen Production. J. Am. Ceram. Soc. 2013, 96, 1158-1162. [CrossRef]

122. Fuoco, L.; Joshi, U.A.; Maggard, P.A. Preparation and Photoelectrochemical Properties of p-type $\mathrm{Cu}_{5} \mathrm{Ta}_{11} \mathrm{O}_{30}$ and $\mathrm{Cu}_{3} \mathrm{Ta}_{7} \mathrm{O}_{19}$ Semiconducting Polycrystalline Films. J. Phys. Chem. 2012, 116, 10490-10497. [CrossRef]

123. Dong, H.; Sun, J.; Chen, G.; Li, C.; Hu, Y.; Lv, C. An advanced Ag-based photocatalyst $\mathrm{Ag}_{2} \mathrm{Ta}_{4} \mathrm{O}_{11}$ with outstanding activity, durability and universality for removing organic dyes. Phys. Chem. Chem. Phys. 2014, 16, 23915-23921. [CrossRef] [PubMed]

124. Dong, H.; Chen, G.; Sun, J.; Li, C. Durability, inactivation and regeneration of silver tetratantalate in photocatalytic $\mathrm{H}_{2}$ evolution. Phys. Chem. Chem. Phys. 2014, 17, 795-799. [CrossRef] [PubMed]

125. Boltersdorf, J.; Zoellner, B.; Fancher, C.; Jones, J.L.; Maggard, P.A. Single and Double-Site Substitutions in Mixed-Metal Oxides: Adjusting the Band Edges Towards the Water Redox Couples. J. Phys. Chem. 2016, 120, 19175-19188. [CrossRef]

126. Boltersdorf, J.; Wong, T.; Maggard, P.A. Synthesis and optical properties of $\mathrm{Ag}(\mathrm{I}), \mathrm{Pb}(\mathrm{II})$, and $\mathrm{Bi}(\mathrm{III})$ tantalate-based photocatalysts. ACS Catal. 2013, 3, 2943-2953. [CrossRef] 
127. McLamb, N.; Sahoo, P.P.; Fuoco, L.; Maggard, P.A. Flux growth of single-crystal $\mathrm{Na}_{2} \mathrm{Ta}_{4} \mathrm{O}_{11}$ particles and their photocatalytic hydrogen production. Cryst. Growth Des. 2013, 13, 2322-2326. [CrossRef]

128. Harb, M.; Masih, D.; Ould-Chikh, S.; Sautet, P.; Basset, J.M.; Takanabe, K. Determination of the electronic structure and UV-Vis absorption properties of $\left(\mathrm{Na}_{2-\mathrm{x}} \mathrm{Cu}_{\mathrm{x}}\right) \mathrm{Ta}_{4} \mathrm{O}_{11}$ from first-principle calculations. J. Phys. Chem. 2013, 117, 17477-17484. [CrossRef]

129. Dong, H.; Chen, G.; Sun, J.; Feng, Y.; Li, C.; Lv, C. Stability, durability and regeneration ability of a novel Ag-based photocatalyst $\mathrm{Ag}_{2} \mathrm{Nb}_{4} \mathrm{O}_{11}$. Chem. Comm. 2014, 50, 6596-6599. [CrossRef] [PubMed]

130. Matsui, M.; Iwase, A.; Kobayashi, H.; Kudo, A. Water Splitting over $\mathrm{CaTa}_{4} \mathrm{O}_{11}$ and $\mathrm{LaZrTa}_{3} \mathrm{O}_{11}$ Photocatalysts with Laminated Structure Consisting of Layers of $\mathrm{TaO}_{6}$ Octahedra and $\mathrm{TaO}_{7}$ Decahedra. Chem. Lett. 2014, 43, 396-398. [CrossRef]

131. Cohen, R.E. Origin of ferroelectricity in perovskite oxides. Nature 1992, 358, 136-138. [CrossRef]

132. Li, L.; Salvador, P.A.; Rohrer, G.S. Photocatalysts with internal electric fields. Nanoscale 2014, 6, $24-42$. [CrossRef] [PubMed]

133. Boltersdorf, J.; Maggard, P.A. Silver-Exchange of Layered Metal Oxides and their Photocatalytic Activities Silver-Exchange of Layered Metal Oxides and their Photocatalytic Activities. ACS Catal. 2013, 3, $2547-2555$. [CrossRef]

(C) 2017 by the authors. Licensee MDPI, Basel, Switzerland. This article is an open access article distributed under the terms and conditions of the Creative Commons Attribution (CC BY) license (http:// creativecommons.org/licenses/by/4.0/). 